NBER WORKING PAPER SERIES

\title{
DETERMINANTS OF FINANCIAL STRESS AND RECOVERY DURING THE GREAT RECESSION
}

Joshua Aizenman

Gurnain Kaur Pasricha

Working Paper 16605

http://www.nber.org/papers/w16605

\author{
NATIONAL BUREAU OF ECONOMIC RESEARCH \\ 1050 Massachusetts Avenue \\ Cambridge, MA 02138
}

December 2010

We would like to thank Amberly Jane Coates for assistance. The views expressed in this paper are those of theauthors. No responsibility for them should be attributed to the Bank of Canada or the National Bureau of Economic Research.

NBER working papers are circulated for discussion and comment purposes. They have not been peerreviewed or been subject to the review by the NBER Board of Directors that accompanies official NBER publications.

(C) 2010 by Joshua Aizenman and Gurnain Kaur Pasricha. All rights reserved. Short sections of text, not to exceed two paragraphs, may be quoted without explicit permission provided that full credit, including $(\odot)$ notice, is given to the source. 
Determinants of Financial Stress and Recovery during the Great Recession

Joshua Aizenman and Gurnain Kaur Pasricha

NBER Working Paper No. 16605

December 2010

JEL No. F32,G15

\begin{abstract}
$\underline{\text { ABSTRACT }}$
In this paper, we explore the link between stress in the domestic financial sector and the capital flight faced by countries in the 2008-9 global crisis. Both the timing of emergence of internal financial stress in developing economies, and the size of the peak-trough declines in the stock price indices was comparable to that in high income countries, indicating that there was no decoupling, even before Lehman Brothers' demise. Deleveraging of OECD positions seemed to dominate the patterns of capital flows during the crisis. While high income countries on average saw net capital inflows and net portfolio inflows during the crisis quarters, compared to net outflows for developing economies, the indicators of banking sector stress were higher for high income economies on average than for developing economies. Internal and external distress during crisis was closely interlinked with common underlying causes of both the severity of stress during the crisis and the recovery. External vulnerabilities were important in both phases, and higher international reserves did not insulate countries from stress.
\end{abstract}

Joshua Aizenman

Department of Economics; E2

1156 High St.

University of California, Santa Cruz

Santa Cruz, CA 95064

and NBER

jaizen@ucsc.edu

Gurnain Kaur Pasricha

Bank of Canada

234 Wellington Street

Ottawa, ON K1A 0G9

Canada

gpasricha@bankofcanada.ca 
The financial crisis that started in the US in 2007 spread rapidly to the rest of the world and resulted in the Great Recession. By mid 2009, the financial crisis was over in most countries, although the evidence on the recession and the tenuous recovery is less clear. In this paper, we aim to understand the spread of financial distress from the US to the rest of the world as well as the determinants of the severity of financial stress and recovery. We distinguish between external and internal financial stress, defined respectively as pressure of capital outflows and pressure inducing declining stock markets, and expanding CBs balance sheets. We ask to what extent the internal financial stress was driven by outflows of capital. Next, we examine the macroeconomic factors that could explain the differences between countries in terms of the severity of internal and external financial stress they experienced during the crisis. We also ask to what extent the differences in the pattern of recovery from financial stress could be explained by the differences in pre-existing fundamentals (rather than endogenous policy responses).

A growing body of literature seeks to examine the cross-country determinants of the incidence of the crisis (Rose and Spiegel, 2010 a, b, c; Blanchard et. al., 2010; Frankel and Saravelos, 2010; Lane and Milesi-Ferretti, 2010; Beckman et. al., 2009, Giannone et. al., 2010). We make three contributions to this literature. First, while most studies focus on real macroeconomic variables, particularly GDP growth, or on a combination of real and financial variables, we focus narrowly on the severity of financial stress, as it was the main 'shock' in the recent crisis. The real impact of the financial crisis would depend not only on the size of the shock but also on the endogenous policy responses and on the real financial linkages within the economy. By focusing on the financial sector stress only, we seek to determine the macroeconomic conditions or linkages that determined the susceptibility of countries to the shock. Second, the emerging consensus narrative on the spread of the crisis holds that the financial crisis spread from the US, first to the high income countries through financial sector linkages and later to emerging markets, which seemed to have 'decoupled' until capital fled these economies in the wake of the Lehman Bankruptcy filing on September $15^{\text {th }}$, 2008. We examine the validity of this narrative by examining the timing of the emergence of financial stress for both high-income and developing economies. Finally, we contribute to the literature by examining the determinants of financial recovery, as well as of financial stress.

The next section describes the indicators of internal and external financial stress and looks at the timing of the emergence of financial stress and the relationship between external and internal stress. Section 3 deals with the determinants of financial stress and section 4 with the determinants of financial recovery. Section 5 concludes. 


\section{Internal and external financial stress during the crisis II.1 Measuring internal and external financial stress}

Our measures of external financial stress are designed to capture the pressure of capital outflows. They include:

(1) Net Capital Inflows Reversals ${ }^{2}$ (or D. Net Capital Inflows): This variable is the difference between net capital inflows during the crisis quarter(s) and the average net capital inflows during 2007, normalized by 2007 GDP. The reason for looking at the difference between crisis quarter net capital inflows and the 2007 values is that in non-crisis periods, the direction of net capital inflows may also reflect equilibrium factors like the age-dependency ratio (relative to the rest of the world). The 2007 average net capital inflows control for these.

(2) Net Portfolio Inflow Reversals (or D. Net Portfolio Inflows): This variable is defined as the difference between net portfolio inflows during crisis quarter(s) and the average net capital inflows during 2007, normalized by 2007 GDP.

(3) The peak exchange market pressure index (EMP). The EMP is defined as the percentage depreciation in SDR exchange rate plus the fall in SDR value of foreign exchange reserves (less gold), normalized by the monetary base. Higher values of EMP denote pressure of outflows. The EMP is computed using monthly data and the peaks are those obtained since January 2008.

Internal Financial stress is measured by the following three variables:

(1) Peak-trough fall in banking or financial sector equity index

(2) Peak-trough fall in a general equity index

(3) Increase in central bank's assets as a percentage of GDP between 2007 and 2009. ${ }^{3}$

Our sample consists of 107 countries, which is the maximum number of countries for which data on at least one financial stress indicator is available, after removing from the universe of countries, those with populations of less than a million (latest available figures), those that were classified as offshore

\footnotetext{
${ }^{2}$ Note that this definition of net capital inflows reversals differs from the commonly used definition in the literature, which defines a reversal as a 'large' switch from net inflows to net outflows.

${ }^{3}$ Where 2009 values were not available, the 2008 values were used. The correlation between this variable and an alternative version - the absolute change between 2009 and 2007 central bank assets normalized by 2007 GDP is 0.7. Moreover, the results in Table 6, on the determinants of financial stress do not change when using this alternative version of internal stress measure.
} 
financial centers or tax havens and USA. We define 'high income' countries as those that are classified by World Bank as high income (OECD or non-OECD), except Singapore, Hong Kong and Israel. ${ }^{4}$ These three and all other countries are referred to as 'low and middle income' countries or 'developing' countries. We refer to 2008Q4 and 2009Q1 as crisis quarters, because these were the quarters where the stress measures peaked for most countries. Table 1 lists, for each quarter from 2007Q1 to 2010Q3, the number of countries that saw their banking sector equity indices or stock market indices bottom in that quarter, the number of countries that saw the lowest net capital inflows or net portfolio inflows relative to 2007 averages in that quarter and the number of countries that saw their EMP peak (since 2008 Jan) in that quarter. 49 out of the 50 countries for which we have data saw their bank equity indices bottom in either 2008Q4 or 2009Q1, and 58 out of the 62 countries saw their stock market indices bottom in these crisis quarters. The peak reversals in net capital inflows or net portfolio inflows were less concentrated, but 31 countries saw these flows trough in one of the crisis quarters. 61 out of the 107 countries for which we have data, saw their exchange market pressure peak in either 2008Q4 or 2009Q1. Having defined 2008Q4 and 2009Q1 as crisis periods, we focus on net capital inflow reversals and net portfolio inflow reversals during each of these two quarters as indicators of crisis severity, in addition to the other stress indicators defined in this section. Throughout the paper, net capital outflows and net portfolio outflows refer to their values relative to 2007 average and expressed as percentage of 2007 GDP.

\section{II.2. Summary Statistics of financial stress indicators:}

The average emerging economy saw a reversal of capital inflows during the crisis, and the net capital outflows exceeded the outflows of portfolio investment. The peak to trough percentage decline in stock prices was about the same, but more dispersed for developing economies than for high income economies. The average percentage decline in banking sector stocks was higher for high income countries.

Table 2 presents the summary statistics on measures of financial stress during the crisis. Developing countries on average saw larger net capital outflows during the crisis than high income countries. Developing countries on average also saw larger net capital outflows in 2009Q1 than in 2008Q4, even though net portfolio inflows had turned positive during the first quarter of 2009. This, coupled with a relative stability of their FDI flows (mean of -0.001 and standard deviation of 1.2 in 2008Q4, and mean of -0.6 and standard deviation of 1.4 in 2009Q1), suggests an important role for other investment, including trade credit and bank lending, and financial derivatives in the reversal of capital inflows to developing countries during the crisis. In fact, 29 out of the 35 developing economics which saw net capital outflows during 2008Q4 also saw net capital outflows exceeding their net portfolio

\footnotetext{
${ }^{4}$ However, Hong Kong and Singapore are also offshore financial centers so excluded from the analysis.
} 
outflows during this quarter (another two countries saw net capital inflows that were lower than their net portfolio inflows). ${ }^{5}$ In 2009Q1, this pattern held for 32 out of 33 developing countries which saw net capital outflows during this quarter. High income countries, on the other hand, saw greater movements in their net portfolio inflows than in net capital inflows. The high income countries continued to be net capital inflow recipients on average during 2008Q4, as well as net portfolio inflow recipients during both quarters. High income countries also exhibited considerably higher dispersion in their level of net portfolio inflows than in their net capital inflows. 17 out of 25 high income countries saw net capital inflows during 2008Q4, but only 10 of these saw net portfolio inflows. These figures suggest that other investment, including bank lending flowed from developing to high income countries, because of deleveraging pressures or to buffer the capital bases of their holding companies. They also suggest that net capital inflows to developing countries recovered later than portfolio flows.

While high income countries on average saw higher net capital inflows and net portfolio inflows during the crisis quarters, compared to net outflows for developing economies, the percentage decline in bank equity prices and stock indices was comparable between the two groups of countries. High income countries saw their central banks respond more on average, by increasing the size of their balance sheets relative to the country's GDP.

\section{II.3. Was there decoupling before Lehman Brothers' demise?}

Stock prices had started declining in all over the world before net capital inflow reversals peaked.

Most emerging as well as high income countries saw their stock markets and the banking sector stock prices peak before Lehman brothers filed for bankruptcy on September 15, 2008, in 2008Q3. Figure 1 shows for each quarter since 2005Q1, the number of countries in each income group, that had their stock markets and bank equity indices peak in that quarter. Most banking sector peaks for high income countries occur in 2007Q2, and all but one high income countries had seen their banking equity index peaks by the end of 2007Q4. Their overall stock market indices peaked later but 86.7 percent of the stock markets in high income countries had peaked by the end of 2007Q4. All of the high income countries had seen their stock markets and bank equity sector indices peak before the end of 2008Q2.

The picture for developing countries is, surprisingly, not much different. 75 percent of developing economy banking sector equity price indices had peaked by the end of 2007Q4, and 59.4 percent of their

\footnotetext{
${ }^{5}$ There are 56 developing economies for which data on both net capital inflows and net portfolio inflows is available for 2008Q4 and 40 for which this data is available for 2009Q1.
} 
stock indices had also peaked before 1 Jan 2008. Moreover, all of the developing country banking sector equity indices had peaked before the end of 2008Q2, and only one developing economy, Tunisia, did not see the beginning of a stock market decline before the end of 2008Q2, i.e. before 30 June, 2008. In contrast, most developing economies saw their net capital inflow reversals peak in 2008Q4, after Lehman's bankruptcy. ${ }^{6}$

Not only was the timing of emergence of internal financial stress in developing economies comparable to that of emergence of internal stress in high income countries, but the size of the declines in the price indices was also comparable. Figures 2 and 3 depict the percentage of total peak-trough decline in bank sector and benchmark stock market indices that had already taken place by the end of 2008Q2, or roughly two months and a half before Lehman's bankruptcy filing. The median decline in banking sector stocks (as percentage of total peak-trough decline for that country) is 51.1 percent, about the level for USA. The median decline is close for the two groups of countries (the median for high income countries is 48.4 and for low income countries 53), as is evident from the relatively equal distribution of blue and red dots around the median line in both the graphs. The declines in the banking sector and overall stock indices in the two groups of countries are comparable even when measured as percentage of peak value (instead of as percentage of total peak to trough decline). For high income countries, the median percentage decline from peak in stock market index by the end of 2008Q2 was 27.5 percent, compared to 25.4 percent for developing economies. The median decline from peak in banking sector stocks in high income countries by the end of 2008Q2 was 36.4 percent, compared to 32.3 percent in developing economies. This pattern is consistent with the possibility that problems in the banking sectors had emerged even in developing countries before the emergence of significant external financial stress, or that the market was pricing the risk of future contagion, i.e. that it did not quite believe in decoupling.

To provide further insight on the issue, it is useful to look at the correlations between the indicators of external financial stress and the peak to trough declines in banking and overall stock prices. The correlations between the measures of external financial stress and peak to trough measures of internal financial stress are presented in Table 3. The peak to trough change in banking sector equity indices is not significantly correlated with any external stress indicator. However, the overall significance masks important differences between high income, which were net recipient of capital inflows during the crisis and developing countries, which on average saw net capital outflows during the crisis. Figure 4 plots the net capital inflow reversals and net portfolio inflow reversals during 2008Q4 and 2009Q1 against the peak trough change in banking sector indices and figure 5 does the same against peak to trough change in

\footnotetext{
${ }^{6}$ The median developing country saw positive net capital inflows (relative to 2007 average) in 2008Q2 and $2008 \mathrm{Q} 3$.
} 
stock market indices. The slopes of the simple regression lines are different for high income and for developing economies. For high income countries, the correlations between capital inflow reversals and peak to trough declines in banking or benchmark stock price indices change signs, and only one out of the eight correlations is significantly different from zero. ${ }^{7}$ However, for the emerging economies, the correlation between peak to trough equity price declines in bank or general stock market indices and net capital inflows is negative and significant in three out of the four cases (Table 4). ${ }^{8}$ The correlation between peak to trough equity price declines in bank or general stock market declines and net portfolio inflows in 2009Q1 are both large in absolute value and significant. The fact that only the correlations in 2009Q1 are significant but not those in 2008Q4 leaves open the possibility of reverse causality - that countries that faced larger net portfolio outflows in 2009Q1 were the ones were the banking sector problems were more acute or where the impact of financial shocks on the overall economy was larger.

In table 5, we present correlations of net capital inflow reversals or net portfolio inflow reversals with quarterly percentage changes in banking sector stock indices and overall stock indices for developing economies only. The quarterly change in stock index or banking sector index is not significantly correlated with net portfolio inflows in any quarter of 2008 or during 2009Q1. The percentage changes in banking sector stocks and in stock market indices are significantly correlated with net capital inflows in both the crisis quarters, i.e. countries with higher net capital inflows during crisis quarters saw smaller declines in stock prices in these quarters. However, the size of the correlations coefficients is not very high - less than 0.48. As we discussed above, stock markets in most countries had achieved considerable decline by 2008Q3, but the correlations between these declines and net capital inflows are not significant until 2008Q4. These results suggest that each country's banking sector stress was not entirely determined by contagion. They are consistent with the possibility that the same factors were driving the two measures.

\section{Determinants of Internal and External Financial Stress}

We next turn to a formal investigation of the determinants of internal and external financial stress. Since the sample is not very large (33 to 70, depending on specification), and there are many potential explanatory measures of the attributes of interest, we ran sequential regressions. Each regression includes 11 explanatory variables. Six of the 11 explanatory variables are common to all regressions, and are

\footnotetext{
${ }^{7}$ The correlation between the change in net capital inflows in 2009Q1 and the peak to trough decline in stock index is -0.37 and has a p-value of 0.08 . Note that the correlations or p-values are not shown in the figures but available on request. Unless otherwise noted, significance is evaluated at 10 percent level.

${ }^{8}$ Note that this table gives the negative of the values on the $\mathrm{x}$-axis in the corresponding figures.
} 
commonly accepted measures of the underlying fundamental that we are trying to capture. These common explanatory variables are:

1. per capita real GDP in 2007 ,

2. international reserves-to-GDP ratio in 2007,

3. an interaction term between international reserves-GDP ratio and a dummy variable indicating whether the country was a recipient of a swap line by the Federal Reserve, the European Central Bank (ECB) or the People’s Bank of China (PBC),

4. Trade-GDP ratio in 2007,

5. a dummy variable for whether the country was a commodity exporter, and

6. de-jure restrictions on capital flows measured by the Chinn-Ito index.

In addition to these six, each regression includes one indicator each of a country's de-facto external exposure, the quality of its institutions, financial development, and banking sector competitiveness or health, as well as an interaction term between the indicator of institutional quality and banking sector competitiveness or health. The indicators used for each category of variables, are:

7. De-facto external exposure:

a. balance sheet exposure, defined as (total external debt-reserves) /GDP,

b. short term balance sheet exposure, defined as short term debt-reserves/GDP,

c. aggregate foreign exchange exposure from Lane and Shambaugh (higher values means the country is long on foreign currency assets),

d. external portfolio debt assets/GDP from Lane and Milesi Ferreti, and

e. portfolio debt liabilities/GDP from Lane and Milesi Ferreti.

8. Institutions:
a. regulatory quality and
b. banking supervision

9. Financial Development:

a. private credit by domestic banks/GDP,

b. stock market value traded/GDP

10. Banking sector competition/health:
a. Herfindahl Hirschman Index (HHI),
b. concentration ratio,
c. net interest margins,
d. bank non-performing loans rate, 
e. bank liquid reserves/assets, and

f. bank capital to asset ratio.

11. An interaction term between the indicator of institutions and banking sector competition/health.

We summarize the results of the regressions in tables 6 and 7. The second column of each table lists the number of regressions in which the explanatory variable in that row was included, the '\% Sig.' column lists the percentage of these regressions in which that explanatory variable was significant at 10 percent level of significance. The cells in this column are shaded dark to light, depending on the number contained. The darkest shadings indicate that the estimated coefficient of the relevant variable is significant (at 10 percent level) in all regressions in which it is included, medium shading that it is significant in 95 percent of the regressions or more but not in all, and a light shading that it is significant in at least 90 percent but less than 95 percent of the regressions in which it is included. The 'Sign' column lists the sign of the estimated coefficient. For variables for which the sign of the coefficient changed with specification, this column lists +/-. The table tells us the sign of the coefficients associated with each explanatory variable and gives us information on the robustness of the impact of this variable.

\section{III.1. Determinants of External Financial Stress}

The results for the determinants of external stress are summarized in table 6. The results indicate that only five of the 33 explanatory variables considered can be robustly associated with deeper external financial stress in either of the crisis quarters. This finding is an improvement over the results of Rose and Spiegel (2010a, b.), who find that only stock market appreciation pre-crisis and closer trade linkages with the US could be linked to the severity of the crisis. Of the variables that are robustly linked to greater capital outflows and greater portfolio outflows in table 6, four are measures of de-facto openness. Countries with greater external portfolio debt assets or liabilities as percentage of GDP in 2007 saw smaller net capital inflows (relative to 2007 levels and expressed as percentage of 2007 GDP) and smaller net portfolio inflows (also relative to 2007 levels and expressed as percentage of 2007 GDP) during each of the crisis quarters. Countries with greater balance sheet exposure, defined as the excess of total external debt over reserves, as percentage of GDP in 2007 were also mose prone to portfolio outflows during the first crisis quarter (2008Q4) and to net capital outflows during 2009Q1. Although this variables is not always significant in the other regressions explaining external stress (net capital inflow reversals in 2008Q4 and net portfolio inflow reversals in 2009Q1), its coefficient is always negative in sign. 
An important result here is the sign and significance of the pre-crisis level of international reserves. Countries with greater international reserves as percentage of GDP in 2007 saw greater net capital outflows and greater net portfolio outflows in the second crisis quarter. To check whether these results are dominated by high income countries which have lower reserves to GDP ratios, we re-ran the regressions for the developing country sample only. For this sample, the reserves/GDP ratio is still negatively related to net capital inflows in all regressions, but significantly different from zero only in 81 percent and 68 percent of regressions for 2008Q4 and 2009Q1 respectively. The coefficient on reserves/GDP changes sign in regressions explaining net portfolio reversals in developing countries. But whenever it is significant (in 42 percent of regressions for 2008Q4 and in 64 percent of the regressions for 2009Q1), it is negative. However, the number of observations in these regressions is very low - between 18 and 49. In figures 6 and 7, we graph the net capital inflows during each quarter in 2008 against the reserves GDP ratio in 2007. The red line in these figures gives the unconditional correlation between the net capital or portfolio inflows and reserves/GDP for developing countries, as opposed to the conditional correlations estimated for the both developing and high income countries through the regressions. Nevertheless, these are instructive, not only because of what these correlations are, but because of what they are not. The correlation between net capital inflow reversals and the 2007 reserves GDP ratio is mildly positive during 2008Q1 to 2008Q3, but negative during 2008Q4. During the first quarter of global financial distress, having higher reserves stockpiles did not reduce the capital outflows for developing countries. Figure 7 shows that the correlation between net portfolio inflows and initial reserves/GDP was negative in the last three quarters of 2008. One possible explanation of the negative correlation between reserves/GDP and external stress during the crisis is related to moral hazard associated with rapid reserve accumulation larger reserves stockpiles may have encouraged build-up of risks by subsidizing cross-border borrowing and discouraging hedging of exposures.

Further, none of the variables measuring institutions or financial development or banking sector competition or health are consistently of the same sign and robustly correlated with the measures of external stress. The only exception is the interaction term between regulatory quality and banking sector liquid reserves to assets, which is significant in 9 out of the 10 regressions in which it is included. However, it is associated with significantly lower net capital inflows during the crisis.

The lack of robust negative association between measures of banking sector health and external financial stress does not necessarily imply that banking sector health was not important in determining the degree of external stress. It may imply that there were important differences between high income and other countries or that our proxies do not adequately capture the health of the banking sector, or the fundamentals that were important in determining susceptibility during this crisis. With the latter 
interpretation, the lack of results here does provide a cautionary note on the adequacy of these measures as part of an early warning system.

\section{III.2. Determinants of Internal Financial Stress}

The results on the determinants of internal financial stress are presented in table 7 . The measures of stock market price changes in table 7 are defined as peak to trough declines, so that a negative coefficient value of an explanatory variable would imply lower fall in these, i.e. lower internal stress. There is no single indicator that is robustly significantly associated with all three measures of internal stress, although at least one measure of de-facto openness is associated with all three measures of internal stress.

While the institutional variables by themselves are not consistently of the same sign or significance in the regressions for the peak to trough decline in banking sector stock prices, several interaction terms with these variables are significant. Countries with better banking supervision and higher bank capital to assets ratio saw smaller declines in banking sector stock prices. Countries with more concentrated banking sectors also had more stable banking sectors in this crisis. However, the same was true for more competitive but better supervised banking sectors. Countries with greater balance sheet exposure, measured by external debt less reserves saw greater declines in banking sector equity prices, while commodity exporters saw lower stress.

Commodity exporters and countries with more developed financial sectors (measured by private credit by domestic banks as percentage of GDP) saw smaller declines in their overall stock markets. Countries with greater de-facto openness measured by portfolio debt assets or liabilities as percentage of GDP saw greater stock market declines. Central banks also seem to have responded more in countries with greater de-facto openness. The coefficients of total external debt minus reserves, external portfolio assets/GDP and external portfolio liabilities/GDP are all positive and significant in every specification. No other variable is consistently significant and of the same sign in alternative specifications explaining the expansion in central bank's assets.

\section{Determinants of the Tentative Recovery}

Our measures of recovery are defined analogously to the measures of stress. We consider the net capital inflows and net portfolio inflows (in excess of the average levels in 2007 and expressed as percentage of 2007 GDP) in each of the quarters 2009Q2, 2009Q3 and 2009Q4. In addition, we consider the trough to peak percentage increase in bank equity price indices and stock price indices, in the period from the trough date to 7 July 2010. 
The regressions results for determinants of net capital inflows are summarized in table 8 and for net portfolio inflows in Table 9. The set of variables explaining the external stress during the recovery phase overlaps to a large extent with the set of variables explaining distress during the crisis quarters. The pattern of net capital inflows during 2009Q2 and 2009Q3 is hard to explain - countries with better banking supervision and greater banking sector liquid reserves to assets ratio saw smaller net capital inflows in 2009Q2 and countries with greater external portfolio debt assets saw lower net capital inflows in 2009Q3. But in 2009Q4, the pattern becomes more identifiable. Countries with greater initial values of balance sheet exposure (external debt less reserves) saw lower net capital inflows during 2009Q4, as did those with greater initial values of portfolio debt assets as percentage of GDP. This suggests that countries with greater external vulnerabilities before the crisis saw greater external financial stress during the crisis as well as slower recovery in net capital inflows.

Once again, higher initial level of international reserves/GDP is associated with lower net capital inflows in 2009Q4. Higher reserves are also negatively correlated with net capital inflows during 2009Q2, although the coefficient is not always significant, and the coefficient of reserves/GDP changes sign in the regressions of net capital inflows in 2009Q2, but is negative whenever it is significant. The overall patterns can be seen in Figure 8. This result is significant because it calls into question the ability of large reserve stockpiles to insulate the country from reversals of capital flows.

As far as net portfolio inflows are concerned, larger external vulnerabilities, measured by greater (total external debt-reserves)/GDP and external portfolio debt assets or liabilities/GDP were associated with lower net portfolio inflows during 2009Q2 (as they were during the crisis quarters), but with higher net portfolio inflows in the subsequent two quarters. Countries with better regulatory quality or banking supervision and more competitive banking sector also saw greater net portfolio inflows during the last quarter of 2009.

The recovery in internal stress measures seems to be unrelated to most macroeconomic variables, whether real sector (GDP per capita, trade/GDP, commodity exporter) or measuring institutional development or banking sector competitiveness, or regulation. However, the recovery in banking sector stock prices is positively related to the measures of de-facto external openness, including external portfolio debt assets of liabilities as percentage of GDP. The banking sector recovery is also positively linked with balance sheet exposure (total external debt less reserves/GDP). Figure 9 graphs the relationships between peak to trough decline in banking sector index and post-crisis trough to peak rise in the index, against the initial balance sheet exposures. The top panel plots the entire sample, whereas the 
bottom panel excludes the outlier, Ireland. Both panels show a positive relationship, although, it seems to be driven by the relationship in high income countries.

The only two variables that are robustly associated with the trough to peak percentage rise in stock index are the aggregate foreign exchange exposure and the private credit by domestic banks as percentage of GDP. The sign of both these variables is negative - i.e. countries that were long in foreign exchange or had better developed banking sectors, saw smaller post-crisis recovery in stock indices.

The results suggest that the internal and external distress was closely interlinked with common underlying causes of both the severity of stress during the crisis and the recovery. External vulnerabilities played a role in determining the severity of external and internal financial stress during the crisis phase, as well as the recovery phase.

\section{Conclusions}

The global crisis of 2008-9 painfully illustrated that, beyond idiosyncratic deviations, practically all countries were exposed to a fast moving, common global shock propagated from the US. Our analysis showed that the timing of emergence of internal financial stress in developing economies was in tandem with the emergence of the stress in high income countries. In addition, the size of the peak-trough declines in the stock price indices, about 60 percent, was comparable to that in high income countries. The main difference seems to be in the greater dispersion of the decline in low and middle countries, with a standard deviation that was twice that of the high income countries. As far as stock markets goes, there was no decupling between developing and high income countries. ${ }^{9}$

We found clear evidence that deleveraging of developed country positions dominated the patterns of capital flows during the crisis. While high income countries on average saw net capital inflows and net portfolio inflows during the crisis quarters, compared to net outflows for developing economies, the indicators of banking sector stress were higher for high income economies on average than for developing economies. The evidence is consistent with the notion that banking systems in the high income countries were, on average, more exposed to pressure, and that the central banks in high income countries responded more aggressively to that pressure. High income countries saw larger average peak to trough declines in bank equity prices than developing countries, and saw their central banks respond more by increasing the size of their balance sheets relative to the country’s GDP.

\footnotetext{
${ }^{9}$ Intriguingly, this is exactly the outcome one may expect with deep diversification of financial markets.
} 
In line with the effects of greater integration of markets, we found that de-facto openness was associated with greater capital outflows and greater portfolio outflows. Specifically, countries with greater external portfolio debt assets or liabilities as percentage of GDP in 2007 saw greater net capital inflow reversals and greater net portfolio reversals during each of the crisis quarters. Countries with greater balance sheet exposure, defined as the excess of total external debt over reserves as percentage of GDP in 2007, were also most prone to portfolio outflows during the first crisis quarter (2008Q4) and to net capital outflows during 2009Q1. Banking sector stock price declines were lower in countries with better banking supervision and higher bank capital to assets ratio. Banking sectors were also more stable in countries with more concentrated banking sectors. Intriguingly, the same was true for more competitive but better supervised banking sectors. Countries with greater external debt less reserves saw greater declines in banking sector stocks.

The results suggest that, while openness increases exposure to global shocks, deeper capital markets and lower balance sheet exposures tend to increase the resilience of markets. Specifically, commodity exporters and countries with more developed financial sectors saw smaller declines in their overall stock markets. Countries with greater de-facto openness measured by portfolio debt assets or liabilities as percentage of GDP saw greater stock market declines. Central banks also seem to have responded more in countries with greater de-facto openness. Small total external debt minus reserves, external portfolio assets/GDP and external portfolio liabilities/GDP are all associated with lower internal financial stress.

We close the paper with analysis of the onset of the tentative recovery following the peak of the crisis. Evidence suggests that countries with greater external vulnerabilities before the crisis saw greater external financial stress during the crisis as well as slower recovery in net capital inflows. Countries with better regulatory quality and more competitive banking sector saw greater net portfolio inflows during the last quarter of 2009. The recovery in banking sector stock prices is positively related to the measures of de-facto external openness, including external portfolio debt assets of liabilities as percentage of GDP. These results suggest that the internal and external distress was closely interlinked with common underlying causes of both the severity of stress during the crisis and the recovery. External vulnerabilities played a role in determining the severity of external and internal financial stress during the crisis phase, as well as the recovery phase. 


\section{References}

Abiad, Abdul, Enrica Detragiche, and Thierry Tressel (2007), “A New Database of Financial Reforms”, unpublished, Washington: International Monetary Fund.

Aizenman Joshua, Yothin Jinjarak, and Donghyun Park (2010), "International reserves and swap lines: substitutes or complements?” NBER Working Paper No. 15804

Thortsen Beck and Asli Demirgüç-Kunt, "Financial Institutions and Markets Across Countries and over Time: Data and Analysis”, World Bank Policy Research Working Paper No. 4943, May 2009.

Berkmen, Pelin, Gaston Gelos, Robert Rennhack and James P Walsh (2009), "The Global Financial

Crisis: Explaining Cross-Country Differences in the Output Impact”, IMF Working Paper WP/09/280.

Blanchard, Olivier, Hamid Faruqee and Mitali Das (2010), “The Initial Impact of the Crisis on Emerging Market Countries” unpublished.

Frankel, Jeffrey A and George Saravelos (2010), “Are Leading Indicators of Financial Crises Useful for Assessing Country Vulnerability?” NBER Working Paper 16047.

Giannone, Domenico, Michele Lenza and Lucrezia Reichlin (2010), "Market Freedom and the Global Recession” unpublished.

Lane, Philip R, and Gian Maria Milesi-Ferretti (2010), “The Cross-Country Incidence of the Global Crisis”, unpublished.

Lane, Philip R. and Gian Maria Milesi-Ferretti (2007), “The external wealth of nations mark II: Revised and extended estimates of foreign assets and liabilities, 1970-2004”, Journal of International Economics 73, November, 223-250.

Lane, Philip R. and Jay C. Shambaugh (2010), "Financial Exchange Rates and International Currency Exposures”, American Economic Review 100(1), 518-540, March 2010

Rose, Andrew K and Mark M Spiegel (2010a), "Cross-Country Causes and Consequences of the 2008 Crisis: An Update”, CEPR Discussion Paper 7901.

Rose, Andrew K and Mark M Spiegel (2010b), “Cross-Country Causes and Consequences of the 2008 Crisis: Early Warning”, Global Journal of Economics, forthcoming.

Rose, Andrew K and Mark M Spiegel (2010c), "Cross-Country Causes and Consequences of the 2008 Crisis: International Linkages and American Exposure”, Pacific Economic Review, forthcoming. 
Table 1: Number of countries with peak financial stress in each quarter since 2007

\begin{tabular}{|c|c|c|c|c|c|}
\hline Quarter & $\begin{array}{c}\text { D.Net } \\
\text { Capital } \\
\text { Inflow, } \\
\text { Trough }\end{array}$ & $\begin{array}{c}\text { D.Net } \\
\text { Portfolio } \\
\text { Inflow, } \\
\text { Trough }\end{array}$ & Peak EMP & $\begin{array}{c}\text { Bank } \\
\text { Equity } \\
\text { Index } \\
\text { Trough }\end{array}$ & $\begin{array}{c}\text { Stock } \\
\text { Index } \\
\text { Trough }\end{array}$ \\
\hline 2007Q1 & 0 & 0 & & 0 & 0 \\
\hline 2007Q2 & 0 & 0 & & 0 & 0 \\
\hline 2007Q3 & 0 & 0 & & 0 & 0 \\
\hline 2007Q4 & 0 & 0 & & 0 & 0 \\
\hline 2008Q1 & 12 & 8 & 14 & 0 & 0 \\
\hline 2008Q2 & 8 & 11 & 6 & 0 & 0 \\
\hline 2008Q3 & 13 & 11 & 14 & 0 & 0 \\
\hline 2008Q4 & 21 & 29 & 43 & 15 & 22 \\
\hline 2009Q1 & 10 & 2 & 18 & 34 & 36 \\
\hline 2009Q2 & 8 & 6 & 6 & 1 & 2 \\
\hline 2009Q3 & 7 & 5 & 2 & 0 & 0 \\
\hline 2009Q4 & 6 & 8 & 3 & 0 & 2 \\
\hline 2010Q1 & 0 & 0 & 1 & 0 & 0 \\
\hline 2010Q2 & 0 & 0 & 0 & 0 & 0 \\
\hline 2010Q3 & 0 & 0 & 0 & 0 & 0 \\
\hline $\begin{array}{c}\text { 2008Q4 or } \\
\text { 2009Q1 }\end{array}$ & 31 & 31 & 61 & 49 & 58 \\
\hline Total & 85 & 80 & 107 & 50 & 62 \\
\hline
\end{tabular}

Note: D. Net Capital Inflows = (Net capital inflows for that quarter - Average quarterly net capital inflow in 2007)*100/GDP in 2007. D. Net Portfolio Inflows $=$ (Net portfolio inflows for that quarter Average quarterly net portfolio inflow in 2007)*100/GDP in 2007. 
Table 2: Summary Statistics, Financial Stress Indicators

\begin{tabular}{|c|c|c|c|c|c|c|c|c|}
\hline & \multicolumn{4}{|c|}{ Low and Middle Income } & \multicolumn{4}{|c|}{ High Income } \\
\hline & $\mathbf{N}$ & Median & Mean & Std. Dev & $\mathbf{N}$ & Median & Mean & Std. Dev \\
\hline $\begin{array}{l}\text { D.Net K Inflows/GDP } \\
\text { (2008Q4 - } 2007 \text { mean) }\end{array}$ & 59 & -0.51 & -0.84 & 3.93 & 25 & 0.28 & 0.17 & 2.41 \\
\hline $\begin{array}{l}\text { D.Net K Inflows/GDP } \\
\text { (2009Q1 - } 2007 \text { mean) }\end{array}$ & 43 & -1.42 & -2.19 & 3.11 & 24 & -0.32 & -0.15 & 1.93 \\
\hline $\begin{array}{l}\text { D.Net Portfolio Inflows/GDP } \\
\text { (2008Q4 - } 2007 \text { mean) }\end{array}$ & 54 & -0.37 & -0.52 & 1.42 & 25 & 0.42 & 0.36 & 6.35 \\
\hline $\begin{array}{l}\text { D.Net Portfolio Inflows/GDP } \\
\text { (2009Q1 - } 2007 \text { mean) }\end{array}$ & 40 & -0.03 & -0.08 & 1.21 & 24 & 0.96 & 1.40 & 3.11 \\
\hline Peak EMP & 90 & 0.15 & 0.20 & 0.18 & 17 & 0.19 & 0.25 & 0.19 \\
\hline $\begin{array}{l}\text { Peak to Trough Fall in Bank } \\
\text { Equity Index (as \% of Peak Value) }\end{array}$ & 24 & 59.2 & 61.8 & 16.0 & 26 & 78.3 & 75.3 & 14.4 \\
\hline $\begin{array}{l}\text { Peak to Trough Fall in Stock } \\
\text { Index (as \% of Peak Value) }\end{array}$ & 32 & 60.3 & 58.3 & 17.3 & 30 & 64.3 & 63.8 & 8.9 \\
\hline $\begin{array}{l}\text { D. (Central Bank Assets/GDP) } \\
(2009-2007)\end{array}$ & 56 & 1.79 & 1.19 & 6.62 & 23 & 0.56 & 4.55 & 10.6 \\
\hline $\begin{array}{l}\text { D.Net K Inflows/GDP (2008Q4 - } 2007 \\
\text { Inflow in 2007)*100/GDP in 2007. D.N } \\
\text { D.Net Portfolio Inflows/GDP (2008Q4 } \\
\text { Portfolio Inflows in 2007)*100/GDP in } \\
\text { January 2010. (Trough-Peak) Bank Equ } \\
\text { values of banking sector stock price ind } \\
\text { benchmark stock market index. D. Cen } \\
\text { central bank's assets to GDP ratio, expr }\end{array}$ & $\begin{array}{l}\text { mean } \\
\text { et K } \\
-200 \\
2007 \\
\text { ity In } \\
\text { ex. ( } \\
\text { tral B }\end{array}$ & $\begin{array}{l}=(\mathrm{Net} \mathrm{Ca} \\
\text { Inflows/GD } \\
\text { mean })= \\
\text { Peak EMl } \\
\text { dex (as \% } \\
\text { rough-Pea } \\
\text { ank Assets } \\
\text { as a percel }\end{array}$ & $\begin{array}{l}\text { ital Inflc } \\
\text { (2009c } \\
\text { Net Portf } \\
\text { is the pe } \\
\text { Peak va } \\
\text { Stock I }\end{array}$ & $\begin{array}{l}\text { ws in } 2008 \mathrm{Q} \\
1 \text { - } 2007 \text { me } \\
\text { lio Inflows } \\
\text { k exchange } \\
\text { lue) = (Trou } \\
\text { dex (as \% o } \\
9-2007 \text { ) is t }\end{array}$ & rket & $\begin{array}{l}\text { age Quarte } \\
\text { fined simil } \\
4-\text { Averas } \\
\text { ressure sin } \\
{ }^{*} 100 / \text { Peak } \\
\text { lue) is sim } \\
\text { e between }\end{array}$ & $\begin{array}{l}\text { ly Net C } \\
\text { rly for } 2 \\
\text { Quarteı } \\
\text { e Januar } \\
\text { or peak } \\
\text { larly defi } \\
009 \text { and }\end{array}$ & $\begin{array}{l}\text { pital } \\
\text { 09Q1. } \\
\text { y Net } \\
2008 \text { and } \\
\text { nd trough } \\
\text { led for the } \\
007 \text { in the }\end{array}$ \\
\hline
\end{tabular}


Table 3: Correlations between Measures of External and Internal Financial Stress: All Countries

\begin{tabular}{|c|c|c|c|c|c|c|c|c|c|}
\hline & & 1 & 2 & 3 & 4 & 5 & $\theta$ & 7 & 8 \\
\hline $\begin{array}{l}\text { D.NetK Inflows/GDP } \\
\text { (2008Q4 - } 2007 \text { mean) }\end{array}$ & 1 & 1 & & & & & & & \\
\hline $\begin{array}{l}\text { D.NetK Inflows/GDP } \\
\text { (2009Q1 - } 2007 \text { mean) }\end{array}$ & 2 & $\begin{array}{l}\mathbf{0 . 5 7} \\
0.00\end{array}$ & 1 & & & & & & \\
\hline $\begin{array}{l}\text { D.Net Portfolio Inflows/GDP } \\
\text { (2008Q4 - } 2007 \text { mean) }\end{array}$ & 3 & $\begin{array}{l}\mathbf{0 . 3 3} \\
0.00\end{array}$ & $\begin{array}{l}0.19 \\
0.14\end{array}$ & 1 & & & & & \\
\hline $\begin{array}{l}\text { D.Net Portfolio Inflows/GDP } \\
\text { (2009Q1 - } 2007 \text { mean) }\end{array}$ & 4 & $\begin{array}{l}\mathbf{0 . 3 7} \\
0.00\end{array}$ & $\begin{array}{l}\mathbf{0 . 3 3} \\
0.01\end{array}$ & $\begin{array}{l}\mathbf{0 . 5 6} \\
0.00\end{array}$ & 1 & & & & \\
\hline Peak EMP & 5 & $\begin{array}{l}-0.17 \\
0.19\end{array}$ & $\begin{array}{l}0.01 \\
0.95\end{array}$ & $\begin{array}{l}0.01 \\
0.93\end{array}$ & $\begin{array}{l}0.20 \\
0.18\end{array}$ & 1 & & & \\
\hline $\begin{array}{l}\text { Peak to Trough Fall in Bank } \\
\text { Equity Index (as \% of Peak Value) }\end{array}$ & 6 & $\begin{array}{l}0.03 \\
0.86\end{array}$ & $\begin{array}{l}-0.20 \\
0.22\end{array}$ & $\begin{array}{l}0.14 \\
0.35\end{array}$ & $\begin{array}{l}0.17 \\
0.28\end{array}$ & $\begin{array}{l}0.02 \\
0.93\end{array}$ & 1 & & \\
\hline $\begin{array}{l}\text { Peak to Trough Fall in Stock } \\
\text { Index (as \% of Peak Value) }\end{array}$ & 7 & $\begin{array}{l}-\mathbf{0 . 2 4} \\
0.09\end{array}$ & $\begin{array}{l}-\mathbf{0 . 5 1} \\
0.00\end{array}$ & $\begin{array}{l}-0.05 \\
0.74\end{array}$ & $\begin{array}{l}-0.08 \\
0.62\end{array}$ & $\begin{array}{l}0.15 \\
0.32\end{array}$ & $\begin{array}{l}\mathbf{0 . 7 4} \\
0.00\end{array}$ & 1 & \\
\hline $\begin{array}{l}\text { D. Central Bank Assets/GDP } \\
(2009-2007)\end{array}$ & 8 & $\begin{array}{l}0.04 \\
0.78\end{array}$ & $\begin{array}{l}-0.11 \\
0.47\end{array}$ & $\begin{array}{l}-\mathbf{0 . 4 5} \\
0.00\end{array}$ & $\begin{array}{l}-0.09 \\
0.54\end{array}$ & $\begin{array}{l}0.07 \\
0.61\end{array}$ & $\begin{array}{l}\mathbf{0 . 3 0} \\
0.08\end{array}$ & $\begin{array}{l}0.23 \\
0.12\end{array}$ & 1 \\
\hline
\end{tabular}

Note: The second row for each variable gives the p-value for the null that the correlation coefficient is zero. The correlations in bold are those that are significantly different from zero at 10 percent level of significance. 
Table 4: Correlations between Measures of External and Internal Financial Stress: Developing Countries

\begin{tabular}{|c|c|c|c|c|c|c|c|c|c|}
\hline & & 1 & 2 & 3 & 4 & 5 & 6 & 7 & 8 \\
\hline $\begin{array}{l}\text { D.NetK Inflows/GDP } \\
\text { (2008Q4 - } 2007 \text { mean) }\end{array}$ & $\bar{~} 1$ & 1 & & & & & & & \\
\hline $\begin{array}{l}\text { D.NetK Inflows/GDP } \\
\text { (2009Q1 - } 2007 \text { mean) }\end{array}$ & 2 & $\begin{array}{l}\mathbf{0 . 5 3} \\
0.00\end{array}$ & 1 & & & & & & \\
\hline $\begin{array}{l}\text { D.Net Portfolio Inflows/GDP } \\
\text { (2008Q4 - } 2007 \text { mean) }\end{array}$ & 3 & $\begin{array}{l}\mathbf{0 . 4 1} \\
0.00\end{array}$ & $\begin{array}{l}-0.05 \\
0.75\end{array}$ & 1 & & & & & \\
\hline $\begin{array}{l}\text { D.Net Portfolio Inflows/GDP } \\
\text { (2009Q1 - } 2007 \text { mean) }\end{array}$ & 4 & $\begin{array}{l}\mathbf{0 . 3 1} \\
0.05\end{array}$ & $\begin{array}{l}\mathbf{0 . 3 0} \\
0.06\end{array}$ & $\begin{array}{l}\mathbf{0 . 4 3} \\
0.01\end{array}$ & 1 & & & & \\
\hline Peak EMP & 5 & $\begin{array}{r}-0.12 \\
0.41\end{array}$ & $\begin{array}{l}-0.04 \\
0.80\end{array}$ & $\begin{array}{l}0.10 \\
0.49\end{array}$ & $\begin{array}{l}0.25 \\
0.14\end{array}$ & 1 & & & \\
\hline $\begin{array}{l}\text { Peak to Trough Fall in Bank } \\
\text { Equity Index (as \% of Peak Value) }\end{array}$ & 6 & $\begin{array}{l}-0.35 \\
0.11\end{array}$ & $\begin{array}{l}\mathbf{- 0 . 7 0} \\
0.00\end{array}$ & $\begin{array}{l}0.09 \\
0.68\end{array}$ & $\begin{array}{l}-0.55 \\
0.02\end{array}$ & $\begin{array}{l}-0.03 \\
0.90\end{array}$ & 1 & & \\
\hline $\begin{array}{l}\text { Peak to Trough Fall in Stock } \\
\text { Index (as \% of Peak Value) }\end{array}$ & 7 & $\begin{array}{r}-\mathbf{0 . 4 6} \\
0.02\end{array}$ & $\begin{array}{l}\mathbf{- 0 . 6 5} \\
0.00\end{array}$ & $\begin{array}{r}-0.12 \\
0.56\end{array}$ & $\begin{array}{r}\mathbf{- 0 . 6 8} \\
0.00\end{array}$ & $\begin{array}{l}0.18 \\
0.33\end{array}$ & $\begin{array}{l}\mathbf{0 . 9 0} \\
0.00\end{array}$ & 1 & \\
\hline $\begin{array}{l}\text { D. Central Bank Assets/GDP } \\
(2009-2007)\end{array}$ & 8 & $\begin{array}{l}0.20 \\
0.21\end{array}$ & $\begin{array}{l}0.03 \\
0.87\end{array}$ & $\begin{array}{l}0.22 \\
0.17\end{array}$ & $\begin{array}{l}0.29 \\
0.11\end{array}$ & $\begin{array}{l}0.05 \\
0.75\end{array}$ & $\begin{array}{l}0.04 \\
0.89\end{array}$ & $\begin{array}{l}0.10 \\
0.64\end{array}$ & 1 \\
\hline
\end{tabular}

Note: The second row for each variable gives the p-value for the null that the correlation coefficient is zero. The numbers in bold are correlations that are significantly different from zero at 10 percent level of significance. 
Table 5: Correlations of quarterly net capital inflows or net portfolio inflows (relative to 2007 average) and quarterly changes in measure of internal financial stress for developing countries.

\begin{tabular}{|c|cc|cc|}
\hline \multirow{2}{*}{} & \multicolumn{2}{|c|}{$\begin{array}{c}\text { D.Net Portfolio } \\
\text { Inflows/GDP_2007 }\end{array}$} & \multicolumn{2}{c|}{ D.Net Capital Inflows/GDP_2007 } \\
\cline { 2 - 5 } & $\begin{array}{c}\text { \% Change in } \\
\text { Bank Equity } \\
\text { Index }\end{array}$ & $\begin{array}{c}\text { \% Change in } \\
\text { Stock Index }\end{array}$ & $\begin{array}{c}\text { \% Change in } \\
\text { Bank Equity } \\
\text { Index }\end{array}$ & $\begin{array}{c}\text { \% Change in } \\
\text { Stock Index }\end{array}$ \\
\hline \multirow{2}{*}{$2008 \mathrm{Q} 1$} & 0.26 & -0.09 & $\mathbf{0 . 4 8}$ & -0.12 \\
& 0.23 & 0.66 & 0.02 & 0.55 \\
$2008 \mathrm{Q} 2$ & 0.18 & 0.17 & 0.17 & 0.06 \\
& 0.43 & 0.38 & 0.45 & 0.78 \\
& -0.02 & 0.13 & -0.09 & -0.01 \\
$2008 \mathrm{Q} 4$ & 0.92 & 0.53 & 0.68 & 0.94 \\
& -0.03 & 0.01 & $\mathbf{0 . 3 3}$ & $\mathbf{0 . 4 0}$ \\
& 0.35 & 0.97 & 0.14 & 0.04 \\
& 0.07 & 0.14 & $\mathbf{0 . 4 6}$ & $\mathbf{0 . 4 2}$ \\
& 0.77 & 0.54 & 0.05 & 0.06 \\
\hline
\end{tabular}

Note: The second row for each quarter gives the p-value for the null that the correlation coefficient is zero. The numbers in bold are correlations that are significantly different from zero at 10 percent level of significance. 



\begin{tabular}{|c|c|c|c|c|c|c|c|c|c|}
\hline \multicolumn{10}{|c|}{ Table 6: Determinants of External Financial Stress } \\
\hline \multirow[b]{3}{*}{ Explanatory Variables } & \multirow[b]{3}{*}{$\begin{array}{l}\text { \# of } \\
\text { Reg. }\end{array}$} & \multicolumn{4}{|c|}{$\Delta$ Net Capital Inflows/GDP 2007} & \multicolumn{4}{|c|}{$\Delta$ Net Portfolio Inflows/GDP 2007} \\
\hline & & \multicolumn{2}{|c|}{ 2008Q4 } & \multicolumn{2}{|c|}{$2009 Q 1$} & \multicolumn{2}{|c|}{$2008 Q 4$} & \multicolumn{2}{|c|}{ 2009Q1 } \\
\hline & & $\%$ Sig. & Sign & $\%$ Sig. & Sign & $\%$ Sig. & Sign & $\%$ Sig. & Sign \\
\hline \multicolumn{10}{|l|}{ All regressions included these... } \\
\hline GDP per capita (constant USD), 2007 & 120 & 73 & + & 13 & $+/-$ & 3 & $+/-$ & 0 & $+/-$ \\
\hline International Reserves less Gold, \% of GDP, 2007 & 120 & 88 & - & 97 & - & 70 & $+/-$ & 100 & - \\
\hline (Reserves/GDP)* Swap Line & 120 & 58 & - & 28 & + & 87 & - & 5 & - \\
\hline Trade, \% of GDP, 2007 & 120 & 83 & + & 13 & $+/-$ & 70 & + & 35 & + \\
\hline Commodity Exporter & 120 & 2 & $+/-$ & 3 & $+/-$ & 6 & $+/-$ & 0 & $+/-$ \\
\hline De-Jure Openness (Chinn-Ito Index), 2007 & 120 & 7 & $+/-$ & 1 & $+/-$ & 0 & $+/-$ & 3 & $+/-$ \\
\hline \multicolumn{10}{|l|}{...and one indicator from each group: } \\
\hline $\begin{array}{l}\text { De-facto External Openness: } \\
\text { (Total External Debt-Reserves), \% of GDP, } 2007\end{array}$ & 24 & 83 & - & 100 & - & 100 & - & 4 & - \\
\hline (Short Term External Debt-Reserves), \% of GDP, 2007 & 24 & 83 & $+/-$ & 71 & - & 0 & $+/-$ & 0 & $+/-$ \\
\hline Aggregate Forex Exposure, 2005 & 24 & 67 & + & 0 & $+/-$ & 0 & $+/-$ & 0 & $+/-$ \\
\hline External Portfolio Debt Assets, \% of GDP, 2007 & 24 & 100 & - & 100 & - & 100 & - & 88 & - \\
\hline External Portfolio Debt Liabilities, \% of GDP, 2007 & 24 & 100 & - & 100 & - & 100 & - & 100 & - \\
\hline \multicolumn{10}{|l|}{ Institutions: } \\
\hline Regulatory Quality, 2007 & 60 & 28 & $+/-$ & 2 & $+/-$ & 2 & $+/-$ & 2 & $+/-$ \\
\hline Banking Supervision, 2007 & 60 & 30 & $+/-$ & 38 & - & 5 & $+/-$ & 2 & $+/-$ \\
\hline \multicolumn{10}{|l|}{ Financial Development: } \\
\hline Private Credit by Domestic Banks, \% of GDP, 2007 & 60 & 7 & $+/-$ & 2 & $+/-$ & 0 & $+/-$ & 0 & $+/-$ \\
\hline Stock Market Value Traded, \% of GDP, 2007 & 60 & 2 & $+/-$ & 8 & $+/-$ & 22 & + & 0 & $+/-$ \\
\hline
\end{tabular}




\begin{tabular}{|c|c|c|c|c|c|c|c|c|c|}
\hline \multicolumn{10}{|c|}{ Table 6 (continued): Determinants of External Financial Stress } \\
\hline \multirow[b]{3}{*}{ Explanatory Variables } & \multirow[b]{3}{*}{$\begin{array}{c}\text { \# of } \\
\text { Reg. }\end{array}$} & \multicolumn{4}{|c|}{$\Delta$ Net Capital Inflows/GDP 2007} & \multicolumn{4}{|c|}{$\Delta$ Net Portfolio Inflows/GDP 2007} \\
\hline & & \multicolumn{2}{|c|}{ 2008Q4 } & \multicolumn{2}{|c|}{$2009 Q 1$} & \multicolumn{2}{|c|}{ 2008Q4 } & \multicolumn{2}{|c|}{ 2009Q1 } \\
\hline & & $\%$ Sig. & Sign & $\%$ Sig. & Sign & $\%$ Sig. & Sign & $\%$ Sig. & Sign \\
\hline \multicolumn{10}{|l|}{ Banking Sector Competition/Health: } \\
\hline Herfindahl Hirschman Index (HHI), 2007 & 20 & 0 & $+/-$ & 5 & + & 0 & $+/-$ & 0 & $+/-$ \\
\hline 3-Bank Concentration ratio, 2007 & 20 & 20 & $+/-$ & 45 & + & 35 & - & 0 & $+/-$ \\
\hline Net Interest Margins, 2007 & 20 & 0 & $+/-$ & 0 & $+/-$ & 0 & $+/-$ & 0 & - \\
\hline Bank Non-Performing Loans Rate, 2006 & 20 & 0 & $+/-$ & 15 & $+/-$ & 5 & $+/-$ & 15 & $+/-$ \\
\hline Bank Liquid Reserves, \% of Assets, 2006 & 20 & 75 & $+/-$ & 5 & $+/-$ & 5 & + & 0 & $+/-$ \\
\hline Bank Capital to Assets ratio, 2006 & 20 & 30 & $+/-$ & 0 & $+/-$ & 40 & + & 0 & $+/-$ \\
\hline \multicolumn{10}{|l|}{ Interactions: } \\
\hline Regulatory Quality*(-HHI) & 10 & 0 & $+/-$ & 30 & + & 0 & - & 0 & - \\
\hline Banking Supervision *(-HHI) & 10 & 0 & + & 10 & + & 0 & $+/-$ & 0 & $+/-$ \\
\hline Regulatory Quality*(-Concentration) & 10 & 0 & $+/-$ & 0 & + & 0 & $+/-$ & 0 & $+/-$ \\
\hline Banking Supervision*(-Concentration) & 10 & 0 & $+/-$ & 0 & $+/-$ & 0 & $+/-$ & 0 & - \\
\hline Regulatory Quality*(-Net Interest Margin) & 10 & 0 & $+/-$ & 0 & $+/-$ & 10 & $+/-$ & 10 & + \\
\hline Banking Supervision*(-Net Interest Margin) & 10 & 0 & $+/-$ & 0 & - & 0 & $+/-$ & 0 & - \\
\hline Regulatory Quality*(-Bank NPL Rate) & 10 & 20 & $+/-$ & 10 & $+/-$ & 0 & $+/-$ & 0 & $+/-$ \\
\hline Banking Supervision*(-Bank NPL Rate) & 10 & 0 & $+/-$ & 30 & - & 10 & - & 0 & $+/-$ \\
\hline Regulatory Quality* Bank Liquid Reserves/Assets & 10 & 90 & - & 0 & $+/-$ & 0 & $+/-$ & 0 & $+/-$ \\
\hline Banking Supervision* Bank Liquid Reserves/Assets & 10 & 40 & - & 0 & $+/-$ & 0 & - & 0 & $+/-$ \\
\hline Regulatory Quality*Bank Capital to Assets Ratio & 10 & 80 & + & 0 & + & 0 & - & 0 & - \\
\hline Banking Supervision*Bank Capital to Assets Ratio & 10 & 60 & $+/-$ & 0 & $+/-$ & 50 & - & 20 & - \\
\hline \multicolumn{10}{|c|}{ 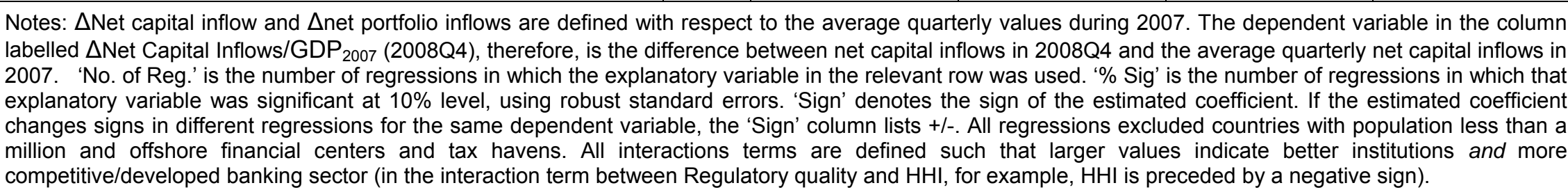 } \\
\hline
\end{tabular}




\begin{tabular}{|c|c|c|c|c|c|c|c|}
\hline \multirow[b]{2}{*}{ Explanatory Variables } & \multirow[b]{2}{*}{$\begin{array}{l}\text { \# of } \\
\text { Reg. }\end{array}$} & \multicolumn{2}{|c|}{$\begin{array}{c}\text { Peak-Trough Fall in } \\
\text { Bank Equity Index }\end{array}$} & \multicolumn{2}{|c|}{$\begin{array}{c}\text { Peak-Trough Fall in } \\
\text { Stock Index }\end{array}$} & \multicolumn{2}{|c|}{$\begin{array}{c}\text { Increase in Centra } \\
\text { Bank Assets/GDP, } \\
2009-2007\end{array}$} \\
\hline & & \% Sig. & Sign & $\%$ Sig. & Sign & \% Sig. & Sign \\
\hline \multicolumn{8}{|l|}{ All regressions included these... } \\
\hline GDP per capita (constant USD), 2007 & 120 & 68 & + & 10 & $+/-$ & 20 & $+/-$ \\
\hline International Reserves less Gold, \% of GDP, 2007 & 120 & 8 & $+/-$ & 67 & $+/-$ & 3 & $+/-$ \\
\hline (Reserves/GDP)*Swap Line & 120 & 11 & $+/-$ & 23 & $+/-$ & 11 & - \\
\hline Trade, \% of GDP, 2007 & 120 & 13 & $+/-$ & 13 & $+/-$ & 2 & $+/-$ \\
\hline Commodity Exporter & 120 & 100 & - & 96 & - & 1 & $+/-$ \\
\hline De-Jure Openness (Chinn-Ito Index), 2007 & 120 & 2 & $+/-$ & 1 & $+/-$ & 34 & - \\
\hline \multicolumn{8}{|l|}{...and one indicator from each group: } \\
\hline \multicolumn{8}{|l|}{ De-facto External Openness: } \\
\hline (Total External Debt-Reserves), \% of GDP, 2007 & 24 & 92 & + & 58 & + & 100 & + \\
\hline (Short Term External Debt-Reserves), \% of GDP, 2007 & 24 & 71 & + & 4 & $+/-$ & 13 & $+/-$ \\
\hline Aggregate Forex Exposure, 2005 & 24 & 88 & - & 25 & $+/-$ & 29 & $+/-$ \\
\hline External Portfolio Debt Assets, \% of GDP, 2007 & 24 & 75 & + & 100 & + & 100 & + \\
\hline External Portfolio Debt Liabilities, \% of GDP, 2007 & 24 & 75 & + & 100 & + & 100 & + \\
\hline \multicolumn{8}{|l|}{ Institutions: } \\
\hline Regulatory Quality, 2007 & 60 & 65 & $+/-$ & 0 & $+/-$ & 3 & $+/-$ \\
\hline Banking Supervision, 2007 & 60 & 75 & $+/-$ & 13 & $+/-$ & 15 & $+/-$ \\
\hline \multicolumn{8}{|l|}{ Financial Development: } \\
\hline Private Credit by Domestic Banks, \% of GDP, 2007 & 60 & 30 & $+/-$ & 90 & - & 12 & $+/-$ \\
\hline Stock Market Value Traded, \% of GDP, 2007 & 60 & 3 & $+/-$ & 33 & $+/-$ & 60 & - \\
\hline
\end{tabular}




\begin{tabular}{|c|c|c|c|c|c|c|c|}
\hline \multirow[b]{2}{*}{ Explanatory Variables } & \multirow[b]{2}{*}{$\begin{array}{l}\text { \# of } \\
\text { Reg. }\end{array}$} & \multicolumn{2}{|c|}{$\begin{array}{l}\text { Peak-Trough Fall in } \\
\text { Bank Equity Index }\end{array}$} & \multicolumn{2}{|c|}{$\begin{array}{l}\text { Peak-Trough Fall in } \\
\text { Stock Index }\end{array}$} & \multicolumn{2}{|c|}{$\begin{array}{c}\text { Increase in Central } \\
\text { Bank Assets/GDP, } \\
\text { 2009-2007 }\end{array}$} \\
\hline & & $\%$ Sig. & Sign & $\%$ Sig. & Sign & \% Sig. & Sign \\
\hline \multicolumn{8}{|l|}{ Banking Sector Competition/Health: } \\
\hline Herfindahl Hirschman Index (HHI), 2007 & 20 & 50 & - & 5 & $+/-$ & 5 & $+/-$ \\
\hline 3-Bank Concentration ratio, 2007 & 20 & 90 & - & 0 & $+/-$ & 0 & $+/-$ \\
\hline Net Interest Margins, 2007 & 20 & 70 & + & 10 & $+/-$ & 40 & $+/-$ \\
\hline Bank Non-Performing Loans Rate, 2006 & 20 & 0 & $+/-$ & 0 & - & 50 & $+/-$ \\
\hline Bank Liquid Reserves, \% of Assets, 2006 & 20 & 15 & $+/-$ & 20 & $+/-$ & 0 & $+/-$ \\
\hline Bank Capital to Assets ratio, 2006 & 20 & 80 & + & 0 & + & 90 & $+/-$ \\
\hline \multicolumn{8}{|l|}{ Interactions: } \\
\hline Regulatory Quality*(-HHI) & 10 & 20 & - & 80 & - & 0 & $+/-$ \\
\hline Banking Supervision *(-HHI) & 10 & 90 & - & 0 & $+/-$ & 30 & - \\
\hline Regulatory Quality*(-Concentration) & 10 & 80 & - & 20 & - & 10 & $+/-$ \\
\hline Banking Supervision*(-Concentration) & 10 & 100 & - & 0 & $+/-$ & 0 & $+/-$ \\
\hline Regulatory Quality*(-Net Interest Margin) & 10 & 0 & $+/-$ & 0 & $+/-$ & 0 & $+/-$ \\
\hline Banking Supervision*(-Net Interest Margin) & 10 & 20 & + & 0 & $+/-$ & 0 & - \\
\hline Regulatory Quality*(-Bank NPL Rate) & 10 & 0 & $+/-$ & 0 & + & 10 & $+/-$ \\
\hline Banking Supervision*(-Bank NPL Rate) & 10 & 0 & + & 0 & $+/-$ & 30 & $+/-$ \\
\hline Regulatory Quality* Bank Liquid Reserves/Assets & 10 & 30 & + & 0 & $+/-$ & 10 & + \\
\hline Banking Supervision* Bank Liquid Reserves/Assets & 10 & 0 & $+/-$ & 0 & $+/-$ & 0 & - \\
\hline Regulatory Quality*Bank Capital to Assets Ratio & 10 & 80 & - & 0 & - & 0 & $+/-$ \\
\hline Banking Supervision*Bank Capital to Assets Ratio & 10 & 100 & - & 0 & - & 80 & + \\
\hline \multicolumn{8}{|c|}{ 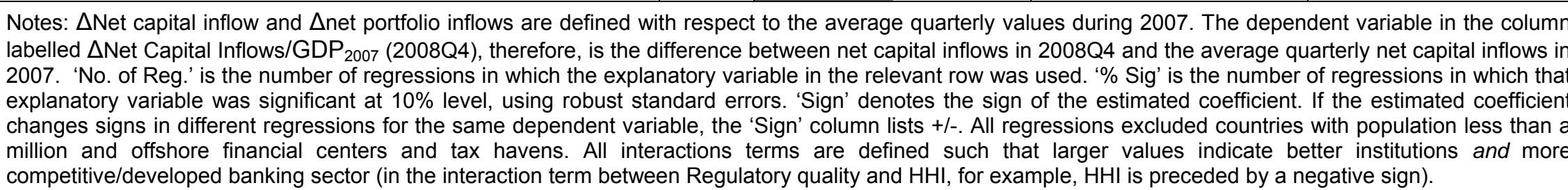 } \\
\hline
\end{tabular}




\begin{tabular}{|c|c|c|c|c|c|c|c|}
\hline \multirow[b]{2}{*}{ Explanatory Variables } & \multirow[b]{2}{*}{$\begin{array}{l}\text { \# of } \\
\text { Reg. }\end{array}$} & \multicolumn{2}{|c|}{$\begin{array}{c}\Delta \text { Net Capital } \\
\text { Inflows/GDP } \\
\text { (2009Q2) }\end{array}$} & \multicolumn{2}{|c|}{$\begin{array}{c}\Delta \text { Net Capital } \\
\text { Inflows/GDP } \\
(2009 Q 3)\end{array}$} & \multicolumn{2}{|c|}{$\begin{array}{c}\Delta \text { Net Capital } \\
\text { Inflows/GDP } \\
(2009 Q 4)\end{array}$} \\
\hline & & $\%$ Sig. & Sign & $\%$ Sig. & Sign & $\%$ Sig. & Sign \\
\hline \multicolumn{8}{|l|}{ All regressions included these... } \\
\hline GDP per capita (constant USD), 2007 & 120 & 20 & + & 0 & $+/-$ & 11 & $+/-$ \\
\hline International Reserves less Gold, \% of GDP, 2007 & 120 & 60 & - & 73 & $+/-$ & 91 & - \\
\hline$($ Reserves/GDP)*Swap Line & 120 & 0 & $+/-$ & 25 & + & 0 & $+/-$ \\
\hline Trade, \% of GDP, 2007 & 120 & 0 & $+/-$ & 15 & $+/-$ & 0 & $+/-$ \\
\hline Commodity Exporter & 120 & 2 & $+/-$ & 36 & + & 0 & $+/-$ \\
\hline De-Jure Openness (Chinn-Ito Index), 2007 & 120 & 0 & $+/-$ & 1 & $+/-$ & 8 & $+/-$ \\
\hline \multicolumn{8}{|l|}{...and one indicator from each group: } \\
\hline \multicolumn{8}{|l|}{ De-facto External Openness: } \\
\hline (Total External Debt-Reserves), \% of GDP, 2007 & 24 & 0 & $+/-$ & 83 & - & 100 & - \\
\hline (Short Term External Debt-Reserves), \% of GDP, 2007 & 24 & 0 & $+/-$ & 13 & - & 50 & - \\
\hline Aggregate Forex Exposure, 2005 & 24 & 46 & + & 4 & + & 4 & + \\
\hline External Portfolio Debt Assets, \% of GDP, 2007 & 24 & 21 & + & 92 & - & 100 & - \\
\hline $\begin{array}{l}\text { External Portfolio Debt Liabilities, \% of GDP, } 2007 \\
\text { Institutions: }\end{array}$ & 24 & 17 & + & 63 & - & 83 & - \\
\hline Regulatory Quality, 2007 & 60 & 3 & $+/-$ & 13 & $+/-$ & 7 & $+/-$ \\
\hline Banking Supervision, 2007 & 60 & 28 & $+/-$ & 7 & $+/-$ & 57 & $+/-$ \\
\hline \multicolumn{8}{|l|}{ Financial Development: } \\
\hline Private Credit by Domestic Banks, \% of GDP, 2007 & 60 & 3 & $+/-$ & 20 & + & 2 & $+/-$ \\
\hline Stock Market Value Traded, \% of GDP, 2007 & 60 & 0 & $+/-$ & 5 & $+/-$ & 25 & + \\
\hline
\end{tabular}




\begin{tabular}{|c|c|c|c|c|c|c|c|}
\hline \multicolumn{8}{|c|}{ Table 8 (continued): Determinants of Recovery in Net Capital Inflows } \\
\hline \multirow[b]{2}{*}{ Explanatory Variables } & \multirow[b]{2}{*}{$\begin{array}{l}\text { \# of } \\
\text { Reg. }\end{array}$} & \multicolumn{2}{|c|}{$\begin{array}{c}\Delta \text { Net Capital } \\
\text { Inflows/GDP } \\
(2009 Q 2)\end{array}$} & \multicolumn{2}{|c|}{$\begin{array}{c}\Delta \text { Net Capital } \\
\text { Inflows/GDP } \\
(2009 Q 3)\end{array}$} & \multicolumn{2}{|c|}{$\begin{array}{c}\Delta \text { Net Capital } \\
\text { Inflows/GDP } \\
(2009 Q 4)\end{array}$} \\
\hline & & $\%$ Sig. & Sign & $\%$ Sig. & Sign & $\%$ Sig. & Sign \\
\hline \multicolumn{8}{|l|}{ Banking Sector Competition/Health: } \\
\hline Herfindahl Hirschman Index (HHI), 2007 & 20 & 0 & $+/-$ & 25 & + & 0 & $+/-$ \\
\hline 3-Bank Concentration ratio, 2007 & 20 & 0 & $+/-$ & 0 & $+/-$ & 0 & $+/-$ \\
\hline Net Interest Margins, 2007 & 20 & 0 & + & 0 & $+/-$ & 0 & $+/-$ \\
\hline Bank Non-Performing Loans Rate, 2006 & 20 & 10 & $+/-$ & 20 & $+/-$ & 15 & $+/-$ \\
\hline Bank Liquid Reserves, \% of Assets, 2006 & 20 & 50 & $+/-$ & 0 & $+/-$ & 0 & $+/-$ \\
\hline Bank Capital to Assets ratio, 2006 & 20 & 20 & $+/-$ & 0 & $+/-$ & 30 & $+/-$ \\
\hline \multicolumn{8}{|l|}{ Interactions: } \\
\hline Regulatory Quality*(-HHI) & 10 & 0 & + & 80 & + & 0 & $+/-$ \\
\hline Banking Supervision *(-HHI) & 10 & 0 & - & 40 & + & 0 & + \\
\hline Regulatory Quality*(-Concentration) & 10 & 10 & + & 50 & + & 0 & $+/-$ \\
\hline Banking Supervision*(-Concentration) & 10 & 0 & $+/-$ & 0 & + & 0 & - \\
\hline Regulatory Quality*(-Net Interest Margin) & 10 & 0 & + & 10 & + & 0 & $+/-$ \\
\hline Banking Supervision*(-Net Interest Margin) & 10 & 0 & + & 0 & $+/-$ & 20 & - \\
\hline Regulatory Quality*(-Bank NPL Rate) & 10 & 0 & $+/-$ & 70 & - & 40 & $+/-$ \\
\hline Banking Supervision*(-Bank NPL Rate) & 10 & 20 & - & 60 & - & 50 & - \\
\hline Regulatory Quality* Bank Liquid Reserves/Assets & 10 & 50 & - & 0 & - & 0 & - \\
\hline Banking Supervision* Bank Liquid Reserves/Assets & 10 & 100 & - & 0 & $+/-$ & 0 & $+/-$ \\
\hline Regulatory Quality*Bank Capital to Assets Ratio & 10 & 0 & $+/-$ & 0 & - & 0 & + \\
\hline Banking Supervision*Bank Capital to Assets Ratio & 10 & 0 & $+/-$ & 0 & $+/-$ & 0 & $+/-$ \\
\hline \multicolumn{8}{|c|}{ 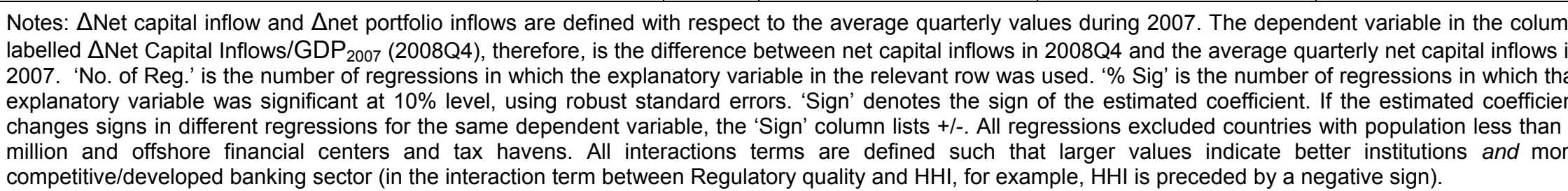 } \\
\hline
\end{tabular}




\begin{tabular}{|c|c|c|c|c|c|c|c|}
\hline \multicolumn{8}{|c|}{ Table 9: Determinants of Recovery in Net Portfolio Inflows } \\
\hline \multirow[b]{2}{*}{ Explanatory Variables } & \multirow[b]{2}{*}{$\begin{array}{l}\text { \# of } \\
\text { Reg. }\end{array}$} & \multicolumn{2}{|c|}{$\begin{array}{l}\Delta \text { Net Portfolio } \\
\text { Inflows/GDP } \\
\text { (2009) }_{200}\end{array}$} & \multicolumn{2}{|c|}{$\begin{array}{l}\Delta \text { Net Portfolio } \\
\text { Inflows/GDP } \\
\text { (2009Q3) }\end{array}$} & \multicolumn{2}{|c|}{$\begin{array}{c}\Delta \text { Net Portfolio } \\
\text { Inflows/GDP } 2007 \\
(2009 Q 4)\end{array}$} \\
\hline & & $\%$ Sig. & Sign & $\%$ Sig. & Sign & $\%$ Sig. & Sign \\
\hline \multicolumn{8}{|l|}{ All regressions included these... } \\
\hline GDP per capita (constant USD), 2007 & 120 & 5 & $+/-$ & 3 & $+/-$ & 3 & $+/-$ \\
\hline International Reserves less Gold, \% of GDP, 2007 & 120 & 25 & $+/-$ & 4 & $+/-$ & 2 & $+/-$ \\
\hline (Reserves/GDP)*Swap Line & 120 & 0 & $+/-$ & 76 & + & 0 & $+/-$ \\
\hline Trade, $\%$ of GDP, 2007 & 120 & 5 & $+/-$ & 71 & + & 2 & $+/-$ \\
\hline Commodity Exporter & 120 & 1 & $+/-$ & 48 & + & 3 & $+/-$ \\
\hline De-Jure Openness (Chinn-Ito Index), 2007 & 120 & 28 & - & 1 & $+/-$ & 0 & $+/-$ \\
\hline \multicolumn{8}{|l|}{...and one indicator from each group: } \\
\hline (Total External Debt-Reserves), \% of GDP, 2007 & 24 & 100 & - & 100 & + & 96 & + \\
\hline (Short Term External Debt-Reserves), \% of GDP, 2007 & 24 & 8 & - & 17 & + & 17 & + \\
\hline Aggregate Forex Exposure, 2005 & 24 & 8 & + & 0 & $+/-$ & 0 & $+/-$ \\
\hline External Portfolio Debt Assets, \% of GDP, 2007 & 24 & 100 & - & 100 & + & 100 & + \\
\hline External Portfolio Debt Liabilities, \% of GDP, 2007 & 24 & 100 & - & 100 & + & 100 & + \\
\hline \multicolumn{8}{|l|}{ Institutions: } \\
\hline Regulatory Quality, 2007 & 60 & 12 & $+/-$ & 0 & $+/-$ & 8 & $+/-$ \\
\hline Banking Supervision, 2007 & 60 & 37 & $+/-$ & 3 & $+/-$ & 3 & $+/-$ \\
\hline \multicolumn{8}{|l|}{ Financial Development: } \\
\hline Private Credit by Domestic Banks, \% of GDP, 2007 & 60 & 0 & $+/-$ & 0 & $+/-$ & 0 & $+/-$ \\
\hline Stock Market Value Traded, \% of GDP, 2007 & 60 & 2 & $+/-$ & 3 & $+/-$ & 10 & $+/-$ \\
\hline
\end{tabular}




\begin{tabular}{|c|c|c|c|c|c|c|c|}
\hline \multicolumn{8}{|c|}{ Table 9 (continued): Determinants of Recovery in Net Portfolio Inflows } \\
\hline \multirow[b]{2}{*}{ Explanatory Variables } & \multirow[b]{2}{*}{$\begin{array}{l}\text { \# of } \\
\text { Reg. }\end{array}$} & \multicolumn{2}{|c|}{$\begin{array}{c}\Delta \text { Net Portfolio } \\
\text { Inflows/GDP } \\
\text { (2009Q2) }\end{array}$} & \multicolumn{2}{|c|}{$\begin{array}{c}\Delta \text { Net Portfolio } \\
\text { Inflows/GDP } \\
(2009 Q 3)\end{array}$} & \multicolumn{2}{|c|}{$\begin{array}{c}\Delta \text { Net Portfolio } \\
\text { Inflows/GDP } \\
\text { (2009Q4) }\end{array}$} \\
\hline & & $\%$ Sig. & Sign & $\%$ Sig. & Sign & \% Sig. & Sign \\
\hline \multicolumn{8}{|l|}{ Banking Sector Competition/Health: } \\
\hline Herfindahl Hirschman Index (HHI), 2007 & 20 & 55 & - & 5 & $+/-$ & 10 & $+/-$ \\
\hline 3-Bank Concentration ratio, 2007 & 20 & 0 & - & 0 & $+/-$ & 0 & + \\
\hline Net Interest Margins, 2007 & 20 & 25 & $+/-$ & 0 & $+/-$ & 0 & $+/-$ \\
\hline Bank Non-Performing Loans Rate, 2006 & 20 & 0 & $+/-$ & 20 & $+/-$ & 0 & $+/-$ \\
\hline Bank Liquid Reserves, \% of Assets, 2006 & 20 & 20 & $+/-$ & 0 & $+/-$ & 0 & $+/-$ \\
\hline Bank Capital to Assets ratio, 2006 & 20 & 5 & $+/-$ & 0 & $+/-$ & 10 & $+/-$ \\
\hline \multicolumn{8}{|l|}{ Interactions: } \\
\hline Regulatory Quality*(-HHI) & 10 & 0 & - & 0 & $+/-$ & 0 & $+/-$ \\
\hline Banking Supervision * $(-\mathrm{HHI})$ & 10 & 50 & - & 0 & - & 90 & + \\
\hline Regulatory Quality*(-Concentration) & 10 & 0 & $+/-$ & 0 & + & 0 & + \\
\hline Banking Supervision*(-Concentration) & 10 & 0 & - & 0 & + & 0 & + \\
\hline Regulatory Quality*(-Net Interest Margin) & 10 & 0 & $+/-$ & 70 & + & 100 & + \\
\hline Banking Supervision*(-Net Interest Margin) & 10 & 70 & + & 0 & $+/-$ & 0 & $+/-$ \\
\hline Regulatory Quality*(-Bank NPL Rate) & 10 & 10 & - & 20 & $+/-$ & 0 & $+/-$ \\
\hline Banking Supervision*(-Bank NPL Rate) & 10 & 0 & $+/-$ & 30 & - & 0 & $+/-$ \\
\hline Regulatory Quality* Bank Liquid Reserves/Assets & 10 & 0 & $+/-$ & 0 & + & 0 & + \\
\hline Banking Supervision* Bank Liquid Reserves/Assets & 10 & 80 & - & 0 & $+/-$ & 0 & - \\
\hline Regulatory Quality*Bank Capital to Assets Ratio & 10 & 40 & - & 0 & - & 0 & - \\
\hline Banking Supervision*Bank Capital to Assets Ratio & 10 & 80 & - & 0 & $+/-$ & 20 & - \\
\hline \multicolumn{8}{|c|}{$\begin{array}{l}\text { Notes: } \Delta \text { Net capital inflow and } \Delta \text { net portfolio inflows are defined with respect to the average quarterly values during } 2007 \text {. The dependent variable in the colum } \\
\text { labelled } \Delta \text { Net Capital Inflows } / G D P 2007 \text { ( } 2008 \mathrm{G} \text { ), therefore, is the difference between net capital inflows in } 2008 \mathrm{Q} 4 \text { and the average quarterly net capital inflows } \\
2007 \text {. 'No. of Reg.' is the number of regressions in which the explanatory variable in the relevant row was used. '\% Sig' is the number of regressions in which the } \\
\text { explanatory variable was significant at } 10 \% \text { level, using robust standard errors. 'Sign' denotes the sign of the estimated coefficient. If the estimated coefficier } \\
\text { changes signs in different regressions for the same dependent variable, the 'Sign' column lists }+/-. \text { All regressions excluded countries with population less than } \\
\text { million and offshore financial centers and tax havens. All interactions terms are defined such that larger values indicate better institutions and mor } \\
\text { competitive/developed banking sector (in the interaction term between Regulatory quality and HHI, for example, HHI is preceded by a negative sign). }\end{array}$} \\
\hline
\end{tabular}




\begin{tabular}{|c|c|c|c|c|c|}
\hline \multicolumn{6}{|c|}{ Table 10: Determinants of internal financial recovery } \\
\hline \multirow[b]{2}{*}{ Explanatory Variables } & \multirow[b]{2}{*}{$\begin{array}{l}\text { \# of } \\
\text { Reg. }\end{array}$} & \multicolumn{2}{|c|}{$\begin{array}{l}\text { Recovery in Bank Equity Index } \\
\text { (Trough-Peak \% rise, post-crisis) }\end{array}$} & \multicolumn{2}{|c|}{$\begin{array}{l}\text { Recovery in Stock Index (Trough- } \\
\text { Peak \% rise, post-crisis) }\end{array}$} \\
\hline & & $\%$ Sig. & Sign & $\%$ Sig. & Sign \\
\hline \multicolumn{6}{|l|}{ All regressions included these... } \\
\hline GDP per capita (constant USD), 2007 & 120 & 7 & $+/-$ & 13 & $+/-$ \\
\hline International Reserves less Gold, \% of GDP, 2007 & 120 & 38 & $+/-$ & 8 & $+/-$ \\
\hline (Reserves/GDP)*Swap Line & 120 & 0 & $+/-$ & 1 & $+/-$ \\
\hline Trade, \% of GDP, 2007 & 120 & 3 & $+/-$ & 33 & $+/-$ \\
\hline Commodity Exporter & 120 & 0 & $+/-$ & 3 & $+/-$ \\
\hline De-Jure Openness (Chinn-Ito Index), 2007 & 120 & 1 & $+/-$ & 0 & $+/-$ \\
\hline \multicolumn{6}{|l|}{$\begin{array}{l}\text {...and one indicator from each group: } \\
\text { De-facto External Openness: }\end{array}$} \\
\hline (Total External Debt-Reserves), \% of GDP, 2007 & 24 & 100 & + & 46 & $+/-$ \\
\hline $\begin{array}{l}\text { (Short Term External Debt-Reserves), \% of GDP, } \\
2007\end{array}$ & 24 & 33 & + & 8 & $+/-$ \\
\hline Aggregate Forex Exposure, 2005 & 24 & 46 & - & 100 & - \\
\hline External Portfolio Debt Assets, \% of GDP, 2007 & 24 & 100 & + & 42 & $+/-$ \\
\hline External Portfolio Debt Liabilities, \% of GDP, 2007 & 24 & 100 & + & 50 & $+/-$ \\
\hline \multicolumn{6}{|l|}{ Institutions: } \\
\hline Regulatory Quality, 2007 & 60 & 5 & $+/-$ & 38 & $+/-$ \\
\hline Banking Supervision, 2007 & 60 & 0 & $+/-$ & 8 & $+/-$ \\
\hline \multicolumn{6}{|l|}{ Financial Development: } \\
\hline Private Credit by Domestic Banks, \% of GDP, 2007 & 60 & 55 & $+/-$ & 98 & - \\
\hline Stock Market Value Traded, \% of GDP, 2007 & 60 & 45 & - & 67 & $+/-$ \\
\hline
\end{tabular}




\begin{tabular}{|c|c|c|c|c|c|}
\hline \multicolumn{6}{|c|}{ Table 11 (continued): Determinants of internal financial recovery } \\
\hline \multirow[b]{2}{*}{ Explanatory Variables } & \multirow[b]{2}{*}{$\begin{array}{l}\text { \# of } \\
\text { Reg. }\end{array}$} & \multicolumn{2}{|c|}{$\begin{array}{l}\text { Recovery in Bank Equity Index } \\
\text { (Trough-Peak \% rise, post-crisis) }\end{array}$} & \multicolumn{2}{|c|}{$\begin{array}{l}\text { Recovery in Stock Index (Trough- } \\
\text { Peak \% rise, post-crisis) }\end{array}$} \\
\hline & & $\%$ Sig. & Sign & $\%$ Sig. & Sign \\
\hline \multicolumn{6}{|l|}{ Banking Sector Competition/Health: } \\
\hline Herfindahl Hirschman Index (HHI), 2007 & 20 & 10 & $+/-$ & 50 & - \\
\hline 3-Bank Concentration ratio, 2007 & 20 & 15 & $+/-$ & 65 & - \\
\hline Net Interest Margins, 2007 & 20 & 0 & $+/-$ & 15 & $+/-$ \\
\hline Bank Non-Performing Loans Rate, 2006 & 20 & 0 & $+/-$ & 10 & $+/-$ \\
\hline Bank Liquid Reserves, \% of Assets, 2006 & 20 & 5 & $+/-$ & 50 & $+/-$ \\
\hline Bank Capital to Assets ratio, 2006 & 20 & 5 & $+/-$ & 10 & + \\
\hline \multicolumn{6}{|l|}{ Interactions: } \\
\hline Regulatory Quality*(-HHI) & 10 & 0 & $+/-$ & 80 & - \\
\hline Banking Supervision *(-HHI) & 10 & 30 & $+/-$ & 50 & - \\
\hline Regulatory Quality*(-Concentration) & 10 & 20 & $+/-$ & 80 & - \\
\hline Banking Supervision*(-Concentration) & 10 & 0 & $+/-$ & 50 & - \\
\hline Regulatory Quality*(-Net Interest Margin) & 10 & 30 & $+/-$ & 40 & - \\
\hline Banking Supervision*(-Net Interest Margin) & 10 & 0 & $+/-$ & 20 & - \\
\hline Regulatory Quality*(-Bank NPL Rate) & 10 & 10 & + & 50 & + \\
\hline Banking Supervision*(-Bank NPL Rate) & 10 & 0 & $+/-$ & 0 & $+/-$ \\
\hline Regulatory Quality* Bank Liquid Reserves/Assets & 10 & 20 & $+/-$ & 0 & $+/-$ \\
\hline Banking Supervision* Bank Liquid Reserves/Assets & 10 & 20 & + & 0 & + \\
\hline Regulatory Quality*Bank Capital to Assets Ratio & 10 & 0 & $+/-$ & 20 & - \\
\hline Banking Supervision*Bank Capital to Assets Ratio & 10 & 0 & - & 0 & $+/-$ \\
\hline \multicolumn{6}{|c|}{$\begin{array}{l}\text { Notes: } \Delta \text { Net capital inflow and } \Delta \text { net portfolio inflows are defined with respect to the average quarterly values during } 2007 \text {. The dependent variable in the column } \\
\text { labelled } \Delta \text { Net Capital Inflows } / \mathrm{GDP}_{2007}(2008 \mathrm{Q} \text { ), therefore, is the difference between net capital inflows in } 2008 \mathrm{Q} 4 \text { and the average quarterly net capital inflows in } \\
2007 \text {. 'No. of Reg.' is the number of regressions in which the explanatory variable in the relevant row was used. '\% Sig' is the number of regressions in which that } \\
\text { explanatory variable was significant at } 10 \% \text { level, using robust standard errors. 'Sign' denotes the sign of the estimated coefficient. If the estimated coefficient } \\
\text { changes signs in different regressions for the same dependent variable, the 'Sign' column lists +/-. All regressions excluded countries with population less than a } \\
\text { million and offshore financial centers and tax havens. All interactions terms are defined such that larger values indicate better institutions and more } \\
\text { competitive/developed banking sector (in the interaction term between Regulatory quality and HHI, for example, HHI is preceded by a negative sign). }\end{array}$} \\
\hline
\end{tabular}


Figure 1: Stock prices had started declining all over the world before net capital inflow reversals peaked.

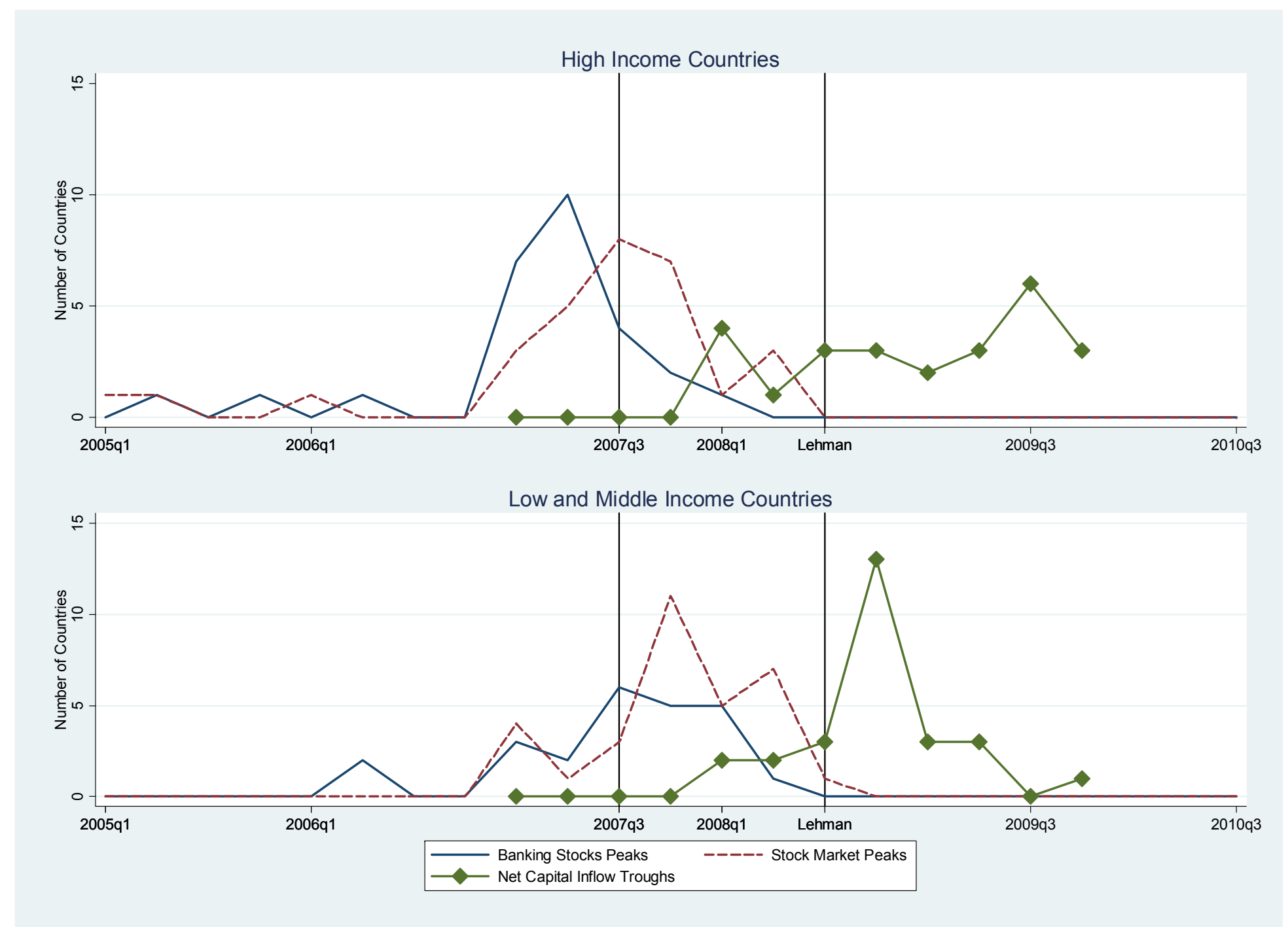

Note: Only countries for which data on at least one equity price index is available are included in computing frequencies for net capital inflow troughs. Full data is presented in Table 1. 
Figure 2: Decline in banking sector equity prices as percentage of total peak to trough decline.

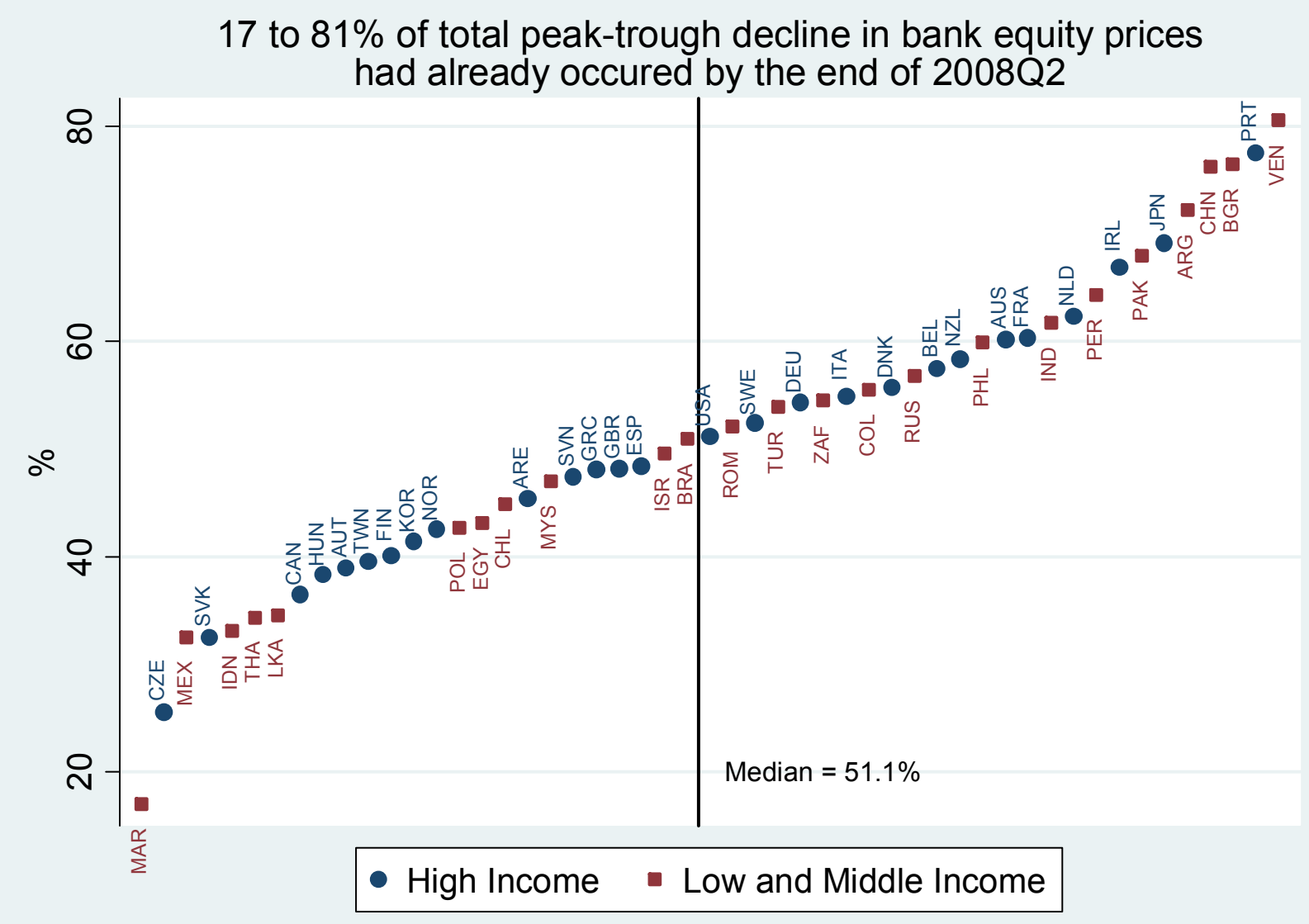


Figure 3: Decline in general stock market price index by end of 2008Q2, as percentage of its peak to trough decline

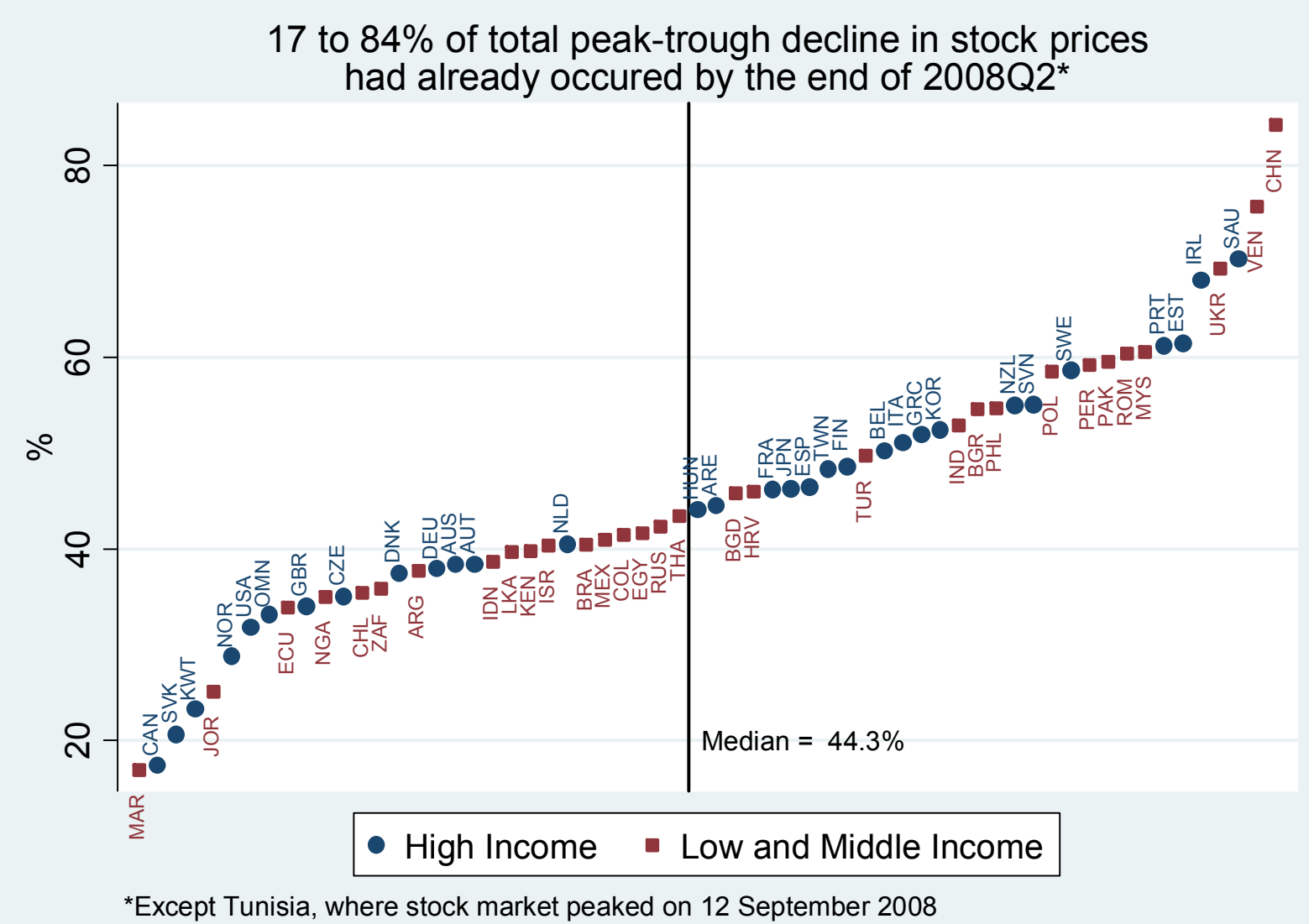



Figure 4: Net capital and portfolio inflow reversals and peak-trough change in banking stock prices

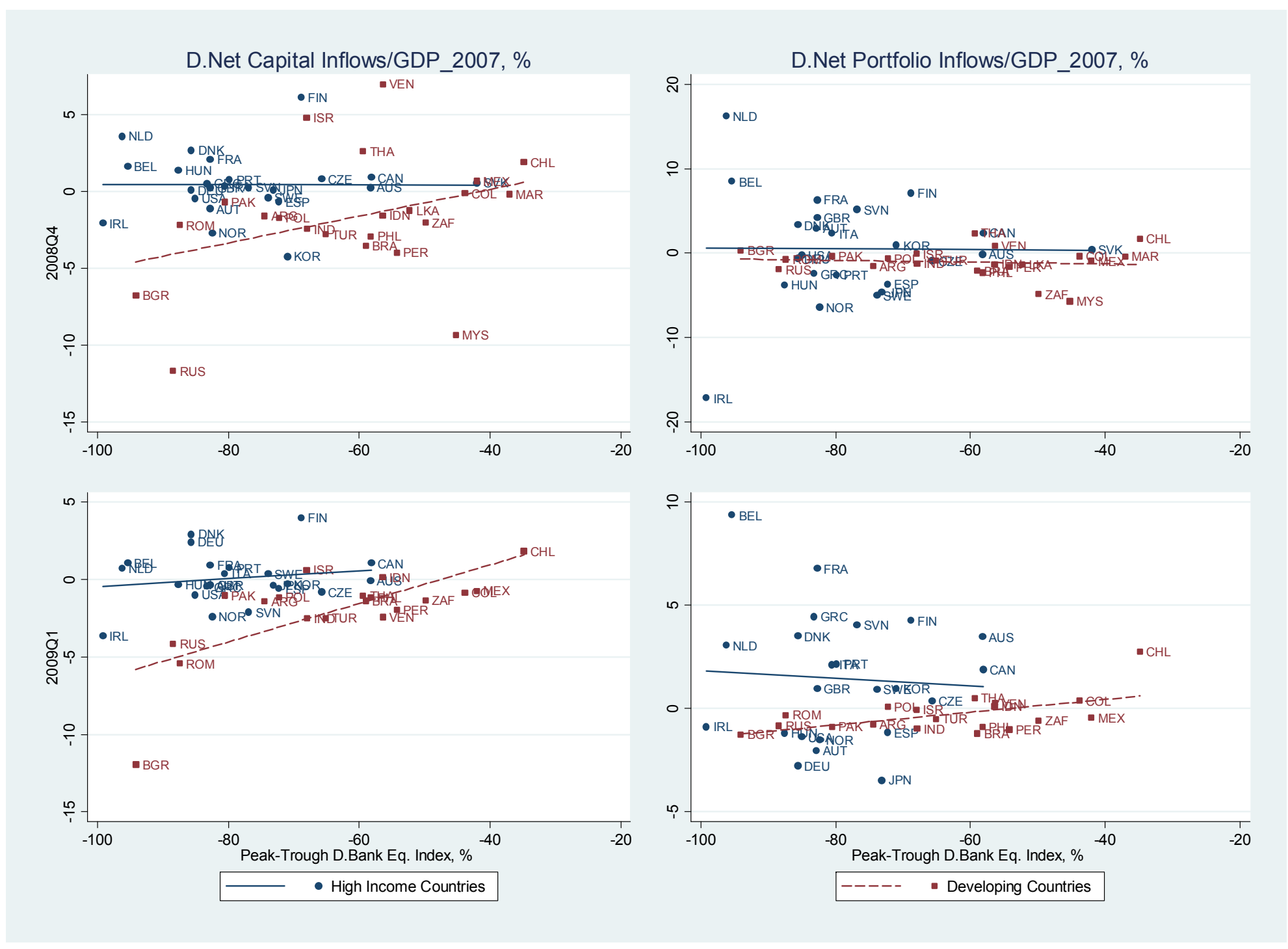


Figure 5: Net capital and portfolio inflow reversals and peak-trough change in stock prices

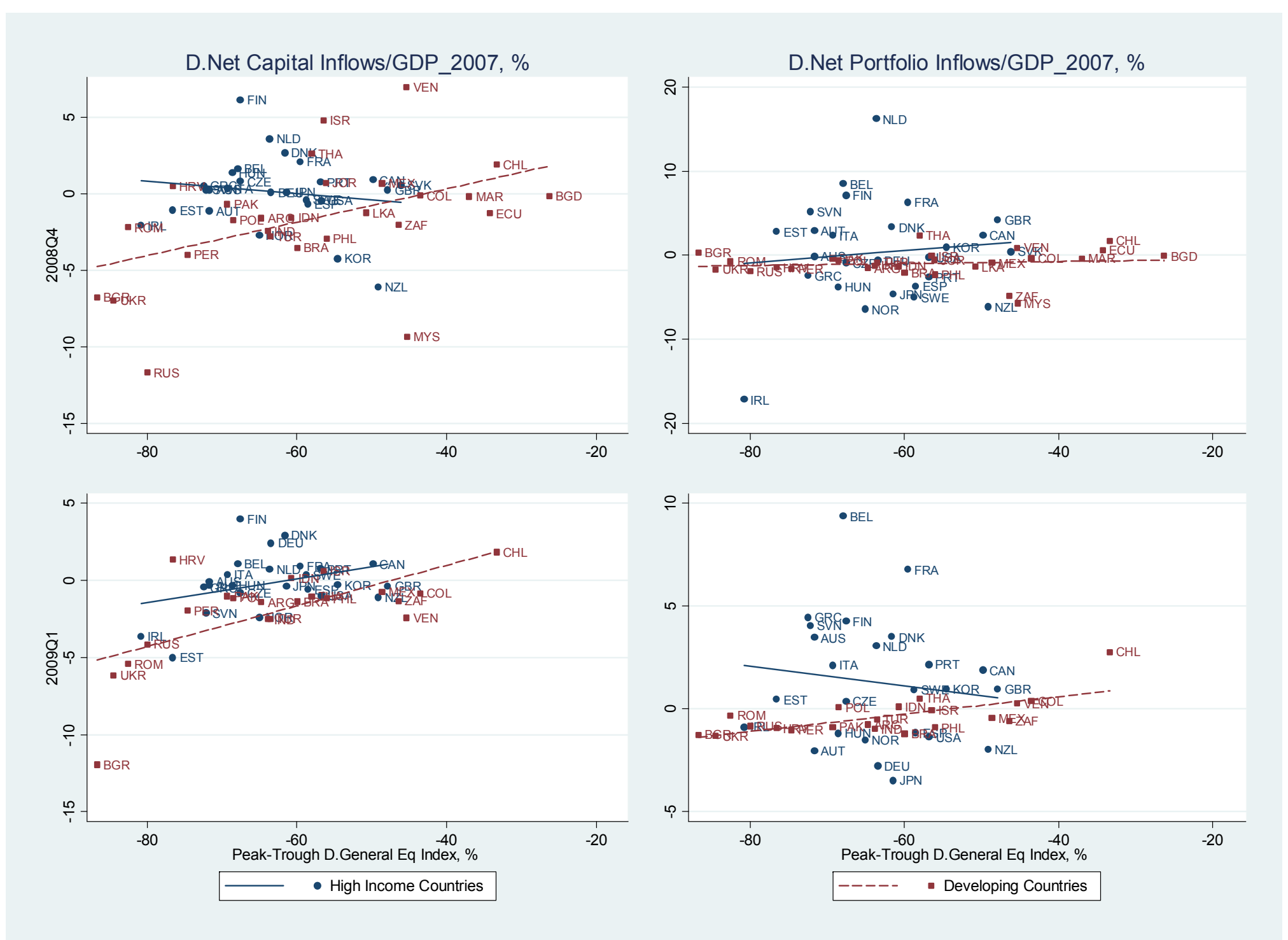


Figure 6: Quarterly net capital inflow reversals during 2008 and 2007 reserves/GDP

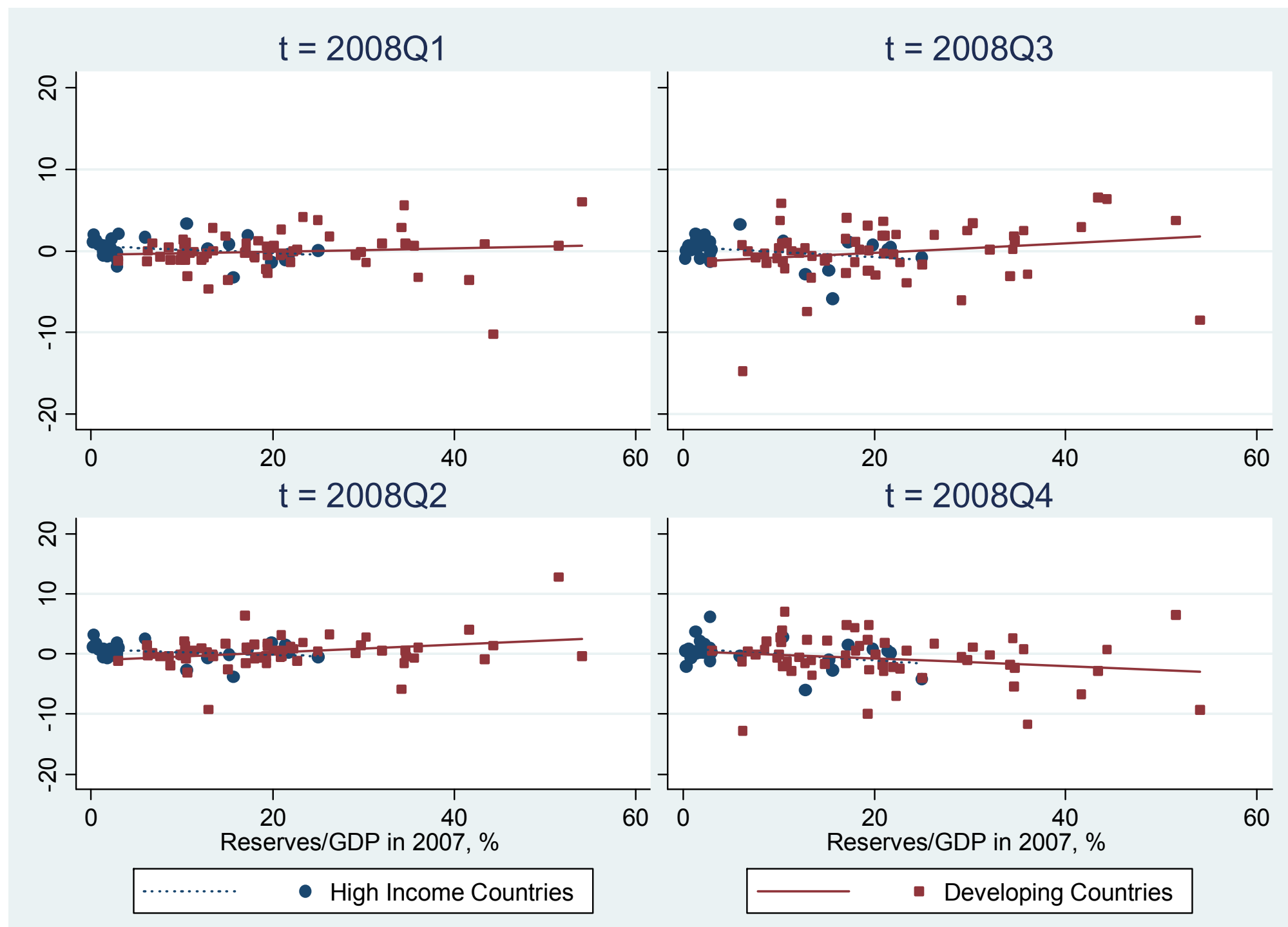


Figure 7: Quarterly net portfolio inflow reversals during 2008 and 2007 reserves/GDP

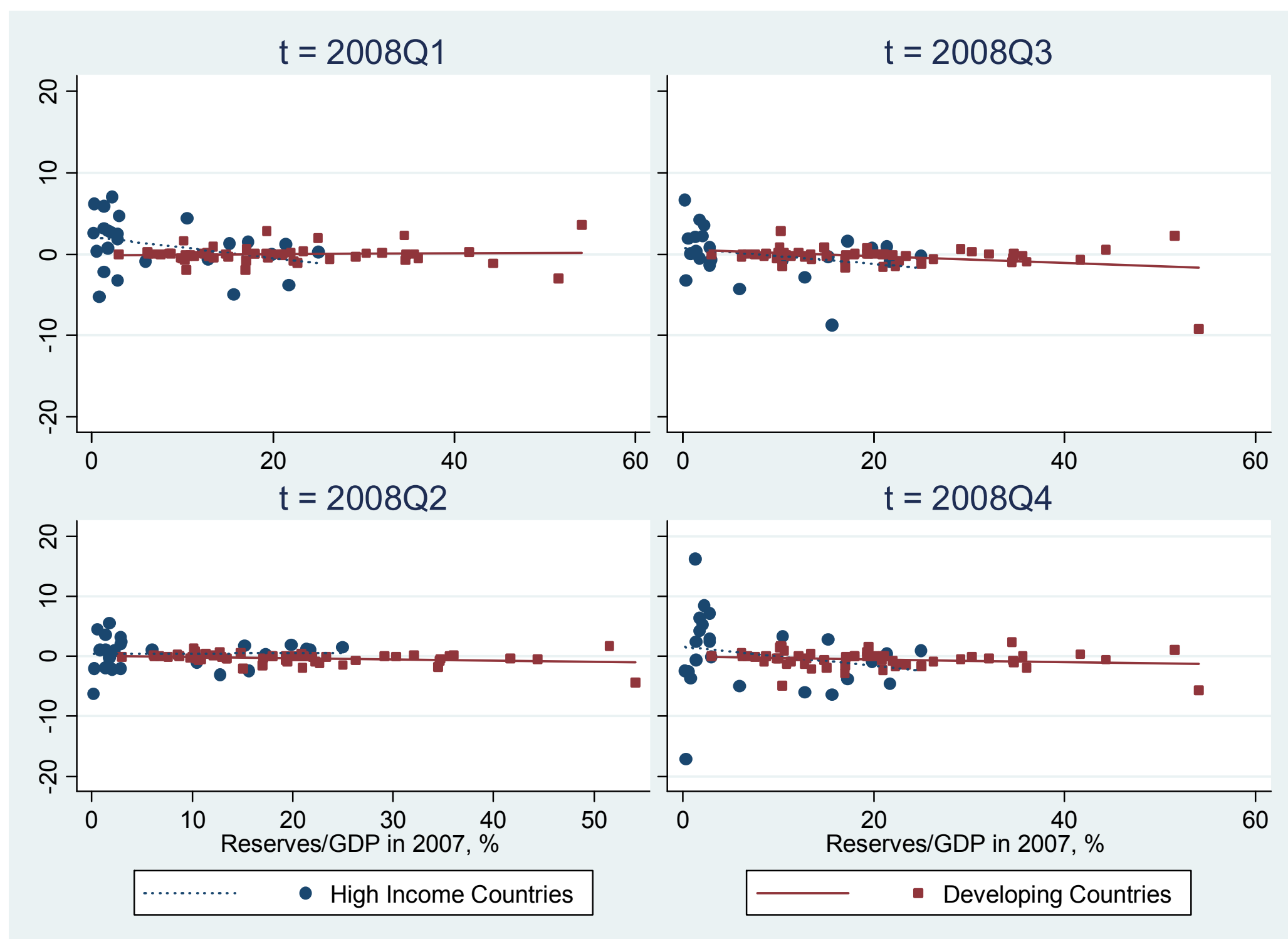


Figure 8: Quarterly net capital inflow reversals and net portfolio inflow reversals during 2009Q2-2009Q4 and 2007 reserves/GDP

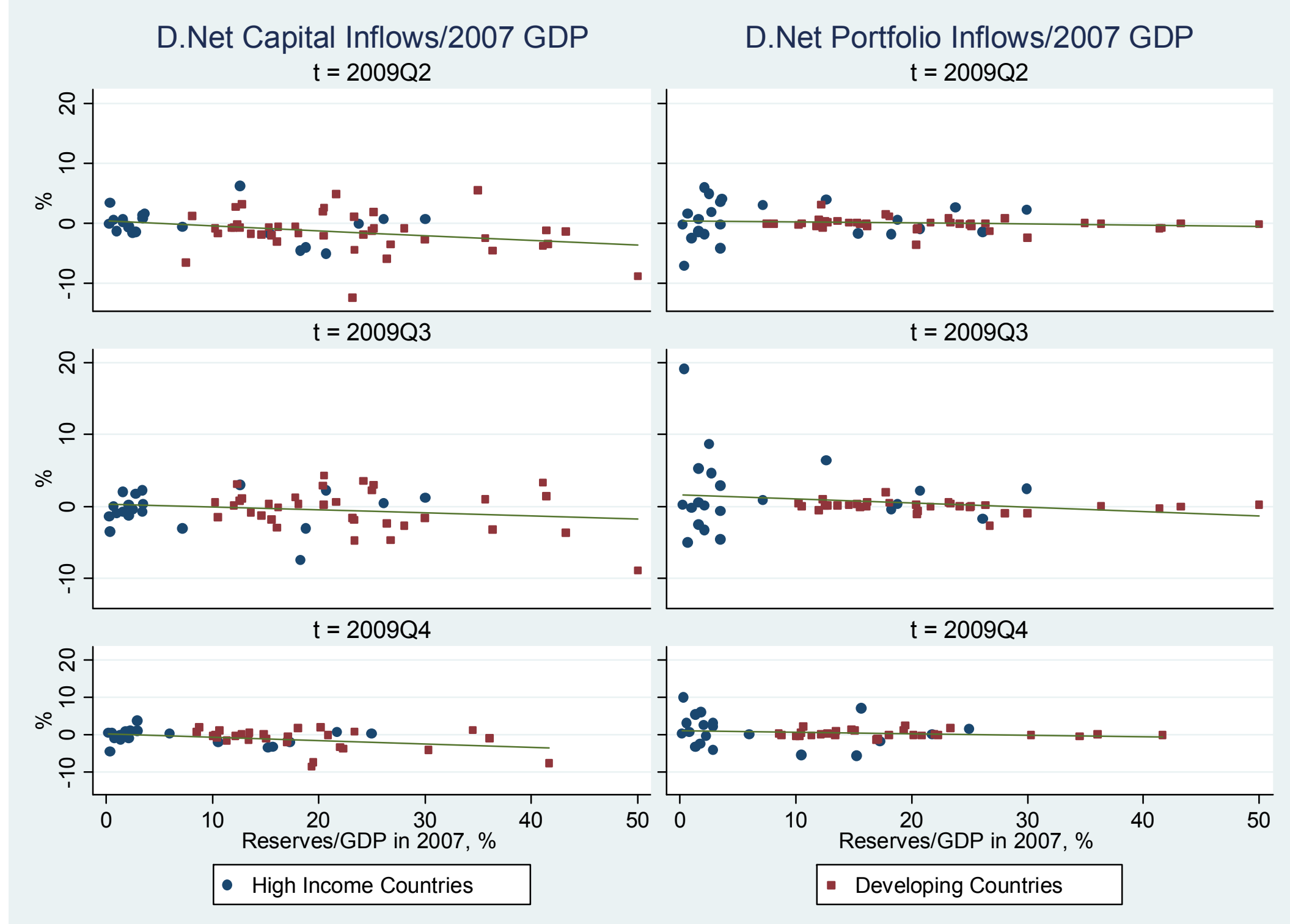


Figure 9: Bank Equity Index changes and Balance Sheet Exposure

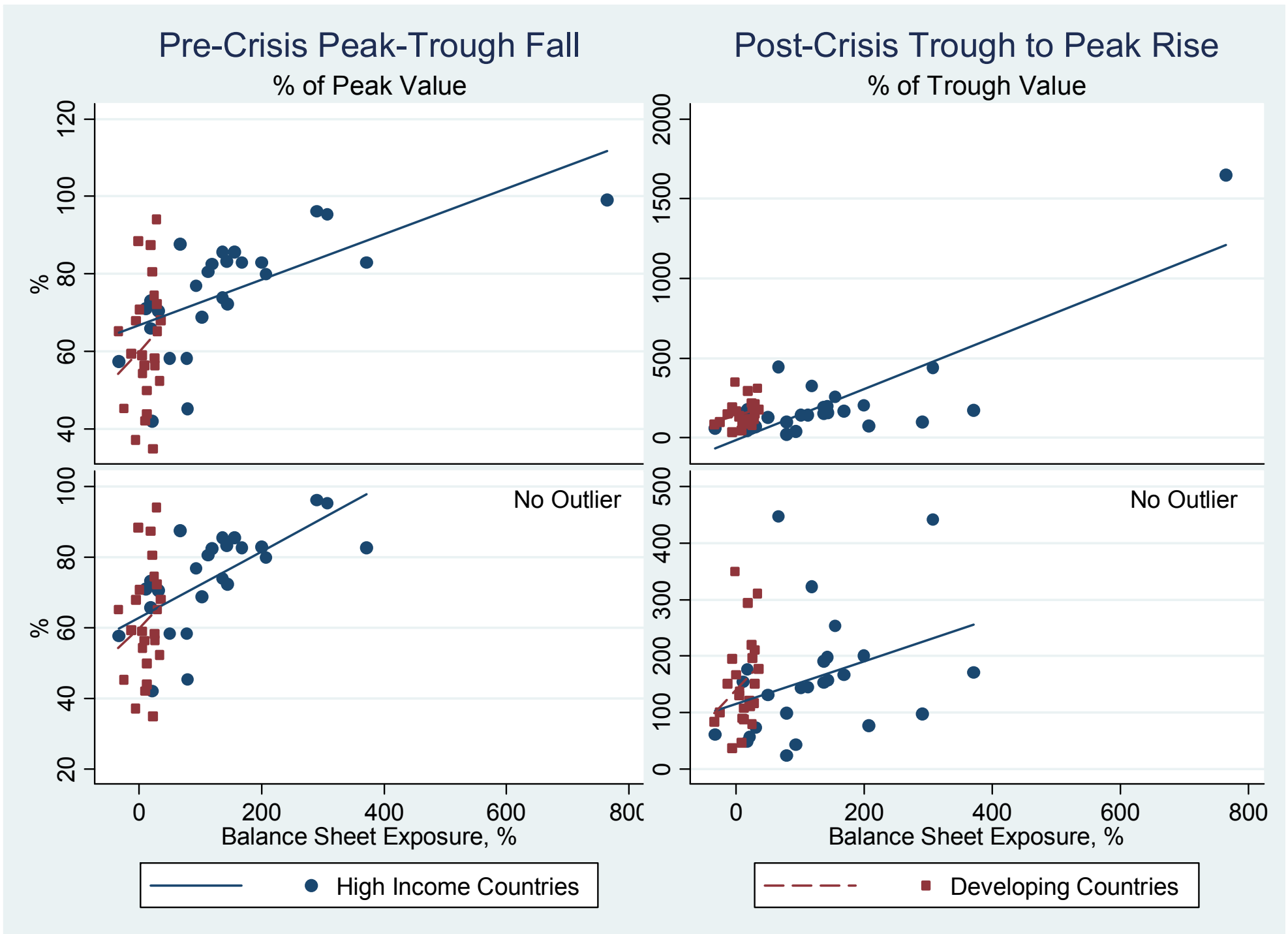

Note: Balance Sheet Exposure is defined as (Total External Debt-Reserves)*100/GDP in 2007. Bottom panels exclude Ireland. 


\section{Data Appendix}

\begin{tabular}{|c|c|c|}
\hline Variable Name & Description & Source \\
\hline $\begin{array}{l}\text { 3-Bank Concentration } \\
\text { Ratio, } 2007\end{array}$ & Assets of three largest banks as a share of assets of all commercial banks. & Beck et. al (2009) \\
\hline $\begin{array}{l}\text { Aggregate Forex } \\
\text { Exposure, } 2005\end{array}$ & $\begin{array}{l}\text { Aggregate foreign currency exposure, as at the end of 2005. It is the difference } \\
\text { between foreign assets and liabilities denominated in foreign currencies, } \\
\text { expressed as a ratio to total foreign assets and liabilities. }\end{array}$ & $\begin{array}{l}\text { Lane and Shambaugh } \\
\text { (2010) }\end{array}$ \\
\hline $\begin{array}{l}\text { Bank Capital to Assets } \\
\text { Ratio, } 2006\end{array}$ & $\begin{array}{l}\text { Bank capital to assets is the ratio of bank capital and reserves to total assets. } \\
\text { Capital and reserves include funds contributed by owners, retained earnings, } \\
\text { general and special reserves, provisions, and valuation adjustments. Capital } \\
\text { includes tier } 1 \text { capital (paid-up shares and common stock), which is a common } \\
\text { feature in all countries' banking systems, and total regulatory capital, which } \\
\text { includes several specified types of subordinated debt instruments that need not be } \\
\text { repaid if the funds are required to maintain minimum capital levels (these } \\
\text { comprise tier } 2 \text { and tier } 3 \text { capital). Total assets include all nonfinancial and } \\
\text { financial assets. }\end{array}$ & World Bank WDI \\
\hline $\begin{array}{l}\text { Bank Liquid Reserves, } \\
\% \text { of Assets, } 2006\end{array}$ & $\begin{array}{l}\text { Ratio of bank liquid reserves to bank assets is the ratio of domestic currency } \\
\text { holdings and deposits with the monetary authorities to claims on other } \\
\text { governments, nonfinancial public enterprises, the private sector, and other } \\
\text { banking institutions. }\end{array}$ & World Bank WDI \\
\hline $\begin{array}{l}\text { Bank Non-Performing } \\
\text { Loans Rate, } 2006\end{array}$ & $\begin{array}{l}\text { Bank nonperforming loans to total gross loans are the value of nonperforming } \\
\text { loans divided by the total value of the loan portfolio (including nonperforming } \\
\text { loans before the deduction of specific loan-loss provisions). }\end{array}$ & World Bank WDI \\
\hline $\begin{array}{l}\text { Banking Supervision, } \\
2007\end{array}$ & $\begin{array}{l}\text { Prudential regulations and supervision of the banking sector. Values range from } 0 \\
\text { to } 3 \text {, with higher values indicating better supervision. }\end{array}$ & $\begin{array}{l}\text { Financial Supervision } \\
\text { database, Abiad et. Al. } \\
2009\end{array}$ \\
\hline Commodity Exporter & $\begin{array}{l}\text { Dummy variable, equal to } 1 \text { if the country is a major commodity exporter. We } \\
\text { follow Rose and Spiegel (2010) in defining } 36 \text { countries as commodity exporters. } \\
\text { These include: } 1 \text {. All past and present OPEC countries; } 2 \text {. Australia, Canada, } \\
\text { Mexico, Kazakhstan, Norway, New Zealand and Russia; } 3 \text {. Any country listed in } \\
\text { CIA world factbook as having more than } 50 \text { percent exports from commodities; } \\
\text { 4. Any country listed in Cashin et. al. (2003). }\end{array}$ & $\begin{array}{l}\text { Rose and Spiegel (2010 } \\
\text { a) }\end{array}$ \\
\hline
\end{tabular}




\begin{tabular}{|c|c|c|}
\hline $\begin{array}{l}\text { D. Net Capital } \\
\text { Inflows/GDP, } \\
\text { (200'i'Q'j'-2007 mean) }\end{array}$ & $\begin{array}{l}\text { (Net Capital inflows in year 200`i', quarter`j' - average quarterly net capital } \\
\text { inflows in 2007)*100/GDP in } 2007 \text {. }\end{array}$ & IMF IFS \\
\hline $\begin{array}{l}\text { D. Net Portfolio } \\
\text { Inflows/GDP, } \\
\text { (200'i'Q'j'-2007 mean) }\end{array}$ & $\begin{array}{l}\text { (Net Portfolio inflows in year } 200{ }^{\prime} i^{\prime} \text {, quarter `j' - average quarterly net portfolio } \\
\text { inflows in 2007)*100/GDP in } 2007 .\end{array}$ & IMF IFS \\
\hline $\begin{array}{l}\text { De-Jure Openness, } \\
2007\end{array}$ & $\begin{array}{l}\text { Chinn-Ito index of the degree of legal restrictions on capital flows for the year } \\
\text { 2007. It varies from }-1.811621 \text { to } 2.531836 \text {, with higher values denoting greater } \\
\text { openness }\end{array}$ & $\begin{array}{l}\text { Chinn and Ito (2006), } \\
\text { updated }\end{array}$ \\
\hline $\begin{array}{l}\text { External Portfolio } \\
\text { Debt Assets, \% of } \\
\text { GDP, } 2007\end{array}$ & & $\begin{array}{l}\text { updated data from Lane } \\
\text { and Milesi-Ferreti } \\
\text { (2007) }\end{array}$ \\
\hline $\begin{array}{l}\text { External Portfolio } \\
\text { Debt Liabilities, \% of } \\
\text { GDP, } 2007\end{array}$ & & $\begin{array}{l}\text { updated data from Lane } \\
\text { and Milesi-Ferreti } \\
\text { (2007) }\end{array}$ \\
\hline $\begin{array}{l}\text { GDP per capita } \\
\text { (constant USD), } 2007\end{array}$ & GDP per capita in 2007, expressed in constant (2000) US dollars. & World Bank WDI \\
\hline $\begin{array}{l}\text { Increase in Central } \\
\text { Bank's Assets, 2009- } \\
2007\end{array}$ & $\begin{array}{l}\text { Central bank's assets/GDP in 2009, \% - Central bank's assets/GDP in 2007, \%. } \\
\text { Central bank assets are computed as the sum of IFS lines 11, 12a, 12e and 12s. } \\
\text { Where } 12 \mathrm{~s} \text { is not available, it is computed as the sum of IFS lines 12b, 12c, 12d } \\
\text { and } 12 \mathrm{~g} \text {. Where } 2009 \text { values were not available, } 2008 \text { values were used. }\end{array}$ & IMF IFS \\
\hline $\begin{array}{l}\text { International Reserves } \\
\text { less Gold, \% of GDP, } \\
2007\end{array}$ & $\begin{array}{l}\text { International Reserves, less gold in current US dollars in 2007, expressed as } \\
\text { percentage of GDP (in current US dollars) in } 2007\end{array}$ & World Bank WDI \\
\hline
\end{tabular}




\begin{tabular}{|c|c|c|}
\hline Variable Name & Description & Source \\
\hline $\begin{array}{l}\text { Herfindahl Hirschman } \\
\text { Index (HHI) }\end{array}$ & $\begin{array}{l}\text { Sum of squared shares of top } 50 \text { firms in industry assets. Individual firm data was } \\
\text { collected from bankscope on all banks (commercial, savings, cooperative and } \\
\text { islamic), bank holding companies and investment banks. Consolidated statements } \\
\text { were used where available. Bankscope provides data on individual firms and to } \\
\text { compute the share of each firm in industry assets, the firm level data was } \\
\text { aggregated for each country-year observation. The coverage of bankscope data is } \\
\text { uneven, due to which some filters were applied. First, wherever BIS data on } \\
\text { industry assets was available (and larger than bankscope totals), the BIS data was } \\
\text { used. Second, (country-year) observations where industry assets or number of } \\
\text { banks available were less than the 1st percentile of all observations were } \\
\text { dropped. Third, observations for which there were extreme changes in number of } \\
\text { banks or industry assets (outside the (1 99) percentile range) were dropped. For } \\
\text { example, if the number of banks in the next year jumped by an extremely large } \\
\text { value, the current year's observations were dropped, but if the next year's number } \\
\text { of banks was unusually lower than the current year's then the next year's } \\
\text { observations were dropped. The percentiles were defined for the whole sample } \\
\text { (all country-year observations). Finally, the same extreme value and extreme } \\
\text { changes filters were applied to the HHI. In cases where the resulting HHI series } \\
\text { had gaps, the data was interpolated using linear interpolation. }\end{array}$ & $\begin{array}{l}\text { BvDep's Bankscope } \\
\text { database and Bank for } \\
\text { International } \\
\text { Settlements }\end{array}$ \\
\hline $\begin{array}{l}\text { Net Capital Inflows } \\
\text { Reversal }\end{array}$ & See D. Net Capital Inflows/GDP & \\
\hline $\begin{array}{l}\text { Net Interest Margins, } \\
2007\end{array}$ & Average net interest margin in banking sector & Beck et. al (2009) \\
\hline $\begin{array}{l}\text { Net Portfolio Inflows } \\
\text { Reversal }\end{array}$ & See D. Net Portfolio Inflows/GDP & \\
\hline $\begin{array}{l}\text { Offshore Financial } \\
\text { Center (OFC) or Tax } \\
\text { haven }\end{array}$ & $\begin{array}{l}\text { OFC data from IMF "Offshore Financial Centers: The Assessment Program -- An } \\
\text { Update" March 12, } 2004 \text { and tax havens from "Offshore Pariahs?" by Mark P. } \\
\text { Hampton and John Christensen" in World Development } 2002\end{array}$ & $\begin{array}{l}\text { IMF and World } \\
\text { Development, } 2002\end{array}$ \\
\hline
\end{tabular}




\begin{tabular}{|c|c|c|}
\hline Variable Name & Description & Source \\
\hline Peak EMP & $\begin{array}{l}\text { The maximum value attained by the monthly exchange market pressure (EMP) } \\
\text { index between } 2007 \text { and } 2008 \text {. EMP is defined as the percentage depreciation in } \\
\text { SDR exchange rate }+ \text { fall in SDR value of foreign exchange reserves less gold, as } \\
\text { percentage of the monetary base. }\end{array}$ & IMF IFS \\
\hline $\begin{array}{l}\text { Peak to Trough fall in } \\
\text { Bank Equity Index }\end{array}$ & $\begin{array}{l}\text { (Peak value of banking sector equity price index between } 2007 \text { and } 2009 \text { - trough } \\
\text { value of banking sector equity price index between } 2007 \text { and 2009)*100/Peak } \\
\text { value of banking sector equity price index between } 2007 \text { and 2009. Where } \\
\text { banking sector equity price index was not available, a financial sector equity } \\
\text { index was used. }\end{array}$ & $\begin{array}{l}\text { Thomson Financial } \\
\text { Datastream }\end{array}$ \\
\hline $\begin{array}{l}\text { Peak to Trough fall in } \\
\text { Stock Index }\end{array}$ & $\begin{array}{l}\text { (Peak value of stock market price index between } 2007 \text { and } 2009 \text { - trough value of } \\
\text { stock market price index between } 2007 \text { and 2009)*100/Peak value of stock } \\
\text { market price index between } 2007 \text { and } 2009\end{array}$ & $\begin{array}{l}\text { Thomson Financial } \\
\text { Datastream }\end{array}$ \\
\hline $\begin{array}{l}\text { Private Credit by } \\
\text { Deposit Money Banks, } \\
\text { \% of GDP, } 2007\end{array}$ & & Beck et. al (2009) \\
\hline $\begin{array}{l}\text { Recovery in Bank } \\
\text { Equity Index }\end{array}$ & $\begin{array}{l}\text { (Post-Crisis Peak (between the crisis trough date and July 7, 2010) in bank equity } \\
\text { index - trough value of bank equity index (between } 2007 \text { and 2009) )*100/trough } \\
\text { value of bank equity index }\end{array}$ & $\begin{array}{l}\text { Thomson Financial } \\
\text { Datastream }\end{array}$ \\
\hline $\begin{array}{l}\text { Recovery in Stock } \\
\text { Index }\end{array}$ & $\begin{array}{l}\text { (Post-Crisis Peak (between the crisis trough date and July 7, 2010) in stock index } \\
\text { - trough value of stock index (between } 2007 \text { and 2009) )*100/trough value of } \\
\text { stock index }\end{array}$ & $\begin{array}{l}\text { Thomson Financial } \\
\text { Datastream }\end{array}$ \\
\hline Regulatory Quality & $\begin{array}{l}\text { Captures perceptions of the ability of government to formulate and implement } \\
\text { sound policies and regulations that permit private sector development. }\end{array}$ & $\begin{array}{l}\text { WB Governance } \\
\text { Indicators }\end{array}$ \\
\hline $\begin{array}{l}\text { (Reserves/GDP)*Swap } \\
\text { Line }\end{array}$ & $\begin{array}{l}\text { Interaction term between International Reserves less Gold, \% of GDP, } 2007 \text { and } \\
\text { Swap Line }\end{array}$ & \\
\hline $\begin{array}{l}\text { Stock Market Value } \\
\text { Traded, \% of GDP, } \\
2007\end{array}$ & & World Bank WDI \\
\hline
\end{tabular}




\begin{tabular}{|l|l|l|}
\hline Variable Name & Description & Source \\
\hline $\begin{array}{l}\text { (Short Term External } \\
\text { Debt -Reserves)/GDP, } \\
\%, 2007\end{array}$ & & World Bank WDI \\
\hline Swap Line & $\begin{array}{l}\text { Dummy variable, equal to 1 if the country was a recipient of a swap line by the } \\
\text { Federal Reserve, European Central Bank or the People's Bank of China }\end{array}$ & Aizenman et. al. (2010) \\
\hline $\begin{array}{l}\text { (Total External Debt - } \\
\text { Reserves)/GDP, \%, } \\
2007\end{array}$ & $\begin{array}{l}\text { Total external debt equals total debt liabilities (portfolio debt + other investment) } \\
\text { from LMF. If missing, then we used total external debt from EDJH database. } \\
\text { Reserves are international reserves less gold, from LMF. GDP is from WDI. All } \\
\text { variables are in current US dollars and as of or as of the end of 2007. }\end{array}$ & $\begin{array}{l}\text { Lane and Milesi-Ferreti } \\
\text { Joint Hub (EDJH) and } \\
\text { WDI }\end{array}$ \\
\hline $\begin{array}{l}\text { Trade, \% of GDP, } \\
2007\end{array}$ & Trade/GDP in 2007, expressed as a percentage & World Bank WDI \\
\hline
\end{tabular}

Note: IMF IFS refers to International Monetary Fund's International Financial Statistics database and World Bank WDI refers to World Bank’s World Development Indicators database. 